\title{
TEMPORAL VARIATION OF WHITE RHINO DUNG ODOURS
}

\author{
COURTNEY MARNEWECK ${ }^{1 *}$, ANDREAS JÜRGENS ${ }^{2}$, ADRIAN M. SHRADER $^{1 \#}$ \\ ${ }^{1}$ School of Life Sciences, University of KwaZulu-Natal, South Africa. \\ ${ }^{2}$ Chemical Plant Ecology, Technische Universität Darmstadt, Germany. \\ ${ }^{*}$ Current address: Mammal Research Institute, Department of Zoology \& Entomology, \\ University of Pretoria, South Africa.
}

Corresponding author: Courtney Marneweck, courtney.marneweck@ gmail.com
ORCID: CM 0000-0002-5064-1979; AJ 0000-0002-5288-0498; AMS 0000-0002-6451-6132

Acknowledgements: We thank Dr Adam Shuttleworth for processing GC-MS samples, Chris Kelly (WildlifeACT Fund) for use of camera traps, and the University of KwaZulu-Natal Gay Langmuir Bursary for Wildlife Research.

\begin{abstract}
In order for an olfactory signal to be effective, it must persist in the environment for an extended period. White rhino dung odours transmit information about sex, age, territorial and oestrous states. As these odours relay important information, temporal changes in the odour emission rate and/or composition may be critical in order for other individuals to obtain this information. Here, we examine how the dung odours of adult white rhinos (male: territorial and non-territorial; female: oestrous and non-oestrous) change over the short (hours) and long (seasons) term using headspace extraction. Additionally, we measure seasonal midden visitation and defecation frequency to link behaviours to seasonal changes in odour longevity. We found that during the dry season, territorial male dung odours persisted for 48 hours, while the odours of all other adults persisted for $>48$ hours. The high temperature and humidity of the wet season did not affect odour longevity of oestrous females, but decreased dung odour longevity (i.e. increased emission) of territorial males, non-territorial males, and non-oestrous females. Despite this reduction, neither males nor females adjusted their seasonal visitation or defecation frequency. With regard to a temporal indictor, 3,7-dimethly-1,6-octadiene signalled dung age during the wet season, while acetophenone signalled dung age during the dry season. Ultimately, our results provide the first detailed account of temporal changes of dung VOCs, and highlight the limitations of dung as a signalling medium.
\end{abstract}

Key Words - Ceratotherium simum, longevity, midden, season, volatile compounds. 


\section{INTRODUCTION}

Mammalian scent marks can originate from a variety of sources, including specialised glandular secretions, urine, and dung. These scent marks relay an assortment of information from territorial state and reproductive condition, to group membership and health (Archunan and Rajagopal 2013; Buesching et al. 2016; Leclaire et al. 2014; Marneweck et al. 2017; Stoffel et al. 2015; Zala et al. 2004). This information is translated by the presence/absence or concentration of specific volatile organic compounds (VOCs). The chemical and physical properties of a VOC govern its volatility and therefore its temporal pattern of emission (Regnier and Goodwin 1977). For example, VOCs with low vapour pressure will persist longer in the environment than VOCs with high vapour pressure (Regnier and Goodwin 1977; Stoddart 1976). Messages within scent marks have different requirements of temporal emission. For example, alarm signals are highly volatile (high vapour pressure) so that they can dissipate once the threat has gone (Verheggen et al. 2010). Contrastingly, territorial signals tend to have low volatility (low vapour pressure) so that they can persist in the environment (Hurst et al. 1998). Due to the source and intended message, scent marks become species specific. For example, pair-living swift foxes (Vulpes velox) mark with faeces in communal latrines almost daily (Darden et al. 2008), suggesting a short odour longevity, but a need to advertise home range ownership. In comparison, solitary territorial male common duikers (Sylvicapra grimmia) defecate almost six times per day, as opposed to nonterritorial females who defecate only three time per day (Lunt and Mhlanga 2011). As both sexes weigh $\sim 15 \mathrm{~kg}$, this increased defecation rate, coupled with male defecation volume being $28 \%$ less than females (123 g vs $170 \mathrm{~g}$ ), suggests that males likely regulate dung volume in order to maximise scent-mark distribution. If correct, this would then allow males to compensate for short dung odour longevity.

External factors may also effect temporal patterns of emission. High levels of humidity and temperature can increase the emission of VOCs (Nimmermark and Gustafsson 2005; Peñuelas and Llusià 2001; Regnier and Goodwin 1977). This causes noise (variation in a signal not attributed to the signal itself) (Wilson et al. 2015), and ultimately decreases the detectability and therefore longevity of an odour. For example, both the detectability and persistence of Carpetan rock lizard (Iberolacerta cyreni) femoral gland secretions were lower at higher temperatures (Martín and López 2013). External factors changing VOC emission are an inevitable source of noise. However, to counteract these external variations, animals could alter their behaviour to ensure effective information transfer. For example, the scent marking frequency of black-tufted marmosets (Callithrix penicillata) was positively correlated with humidity (Oliveira and Macedo 2010), while aardwolves (Proteles cristata) increased scent marking during the summer wet season (Marneweck et al. 2015).

Marking with glandular secretions appears more stable than marking with urine, (i.e. the odours remain unchanged for longer). For example, glandular secretions from European badgers (Meles meles) remain unchanged for 72 hours (Buesching et al. 2002). Further, klipspringers (Oreotragus oreotragus) responded to glandular marks 168 hours (i.e. seven days) after deposition (Roberts 1998). In comparison, male guinea pigs (Cavia porcellus) only responded to female urine that was $<48$ hours old (Beauchamp and Berüter 1973), while 
male rats (Rattus norvegicus) only responded to oestrous urine that was $\leq 24$ hours old (Lydell and Doty 1972).

Despite many mammals marking with dung (Brachares and Arcese 1999; Ralls and Smith 2004; Roper et al. 1993), the detailed temporal changes of dung VOCs have not been investigated. White rhinos (Ceratotherium simum) scent mark using dung deposited in communal piles called middens (Owen-Smith 1973). Territorial males defecate between 2-3 times a day, but only in the same midden about once every ten days (Kretzschmar 2002; Marneweck et al. unpublished data; Owen-Smith 1973). In contrast, non-territorial males and adult females tend to defecate in the same midden only once every 30 days (Marneweck et al. unpublished data). When visiting middens, territorial males defecate $50 \%$ of the time. In the instances when they do not defecate, these males spend time sniffing the dung left by other individuals (Marneweck et al. unpublished data). Surprisingly, when territorial males ( 2300 $\mathrm{kg}$ body mass) do defecate, they defecate in smaller volumes than adult non-territorial males ( $2300 \mathrm{~kg}$ body mass) (Marneweck et al. unpublished data). This may be due to dung being a physiologically limited resource, and thus by depositing small amounts per defecation, territorial males are likely able to defecate in more middens per day, located over a wider area within their territories. With this in mind, white rhinos may be able to alter their defecation rate if season (i.e. temperature and humidity) affects temporal changes in dung odour, in order to maintain signal transmission.

Dung odour profiles from white rhinos transmit information on sex, age, male territorial status, and oestrous state (Marneweck et al. 2017). For males, in particular territorial males, middens are used to advertise territory ownership (Owen-Smith 1973). Thus, it would be evolutionary advantageous for a territorial signal to persist for a long time. If an odour lasts for several days, males could spend less time remarking and more time finding mates, ultimately increasing fitness (Gosling and Roberts 2001a; Owen-Smith 1973). However, if the longevity of these profiles is limited, territorial males may be able to compensate by increasing the frequency with which they defecate in middens, especially when the duration of the signal is reduced (e.g. wet season). However, as dung is physiologically limited, territorial males may not be able to increase the frequency with which they defecate in specific middens. White rhinos employ a polygynous mating strategy, where territorial males mate with multiple females within their territory (White et al. 2007). Female oestrus cycles last approximately 30 days, with oestrus lasting 1-3 days (Lindemann 1982; van der Goot et al. 2015). For females, middens are likely used to advertise reproductive state and assess potential mates (Owen-Smith 1973). Breeding occurs yearround but there is an observed peak at the beginning of the wet season, following flushes of green grass (Owen-Smith 1973; Owen-Smith 1988). As female white rhinos range farther than territorial males (up to 10 times the area) (Owen-Smith 1973), and the duration of oestrus is so short, it would be advantageous for oestrous odours to last longer than nonoestrous odours to help ensure that males locate any oestrous females passing through their territories. Yet, it is uncertain if this is the case. To investigate the temporal changes in the VOCs of both male and female white rhino dung, we assess the longevity of their dung odours, explore temporal changes in odour composition, and investigate marking frequency and its relation to odour longevity. 


\section{METHODS AND MATERIALS}

Collection of Dung Odours. We conducted our study in the $896 \mathrm{~km}^{2}$ Hluhluwe-iMfolozi Park, KwaZulu-Natal, South Africa. Here we collected 66 dung samples from different adult male (territorial and non-territorial) and adult female (oestrous and non-oestrous) white rhinos (Table 1). We identified individuals through variations in horn shape and other distinguishing characteristics, and defined adults as individuals $>7$ years old, based on body size and horn development (Hillman-Smith et al. 1986). Territorial males were identified as adult males performing territorial behaviours (i.e. dung kicking, spray urinating) and nonterritorial as adult males not performing these behaviours (Owen-Smith 1971; Owen-Smith 1973). Oestrous females were identified via the behavioural reactions of males towards them (e.g. following and mounting the female), and non-oestrous identified as females without the attachment of an adult male (Owen-Smith 1973).

We collected approximately $800 \mathrm{~g}$ of dung per individual, either one dung bolus or a collection of scattered dung in the case of territorial males. To collect odours over time, we removed a dung bolus from the midden, relocated it to the research camp, and left the dung samples unprotected outside on natural substrate (i.e. short grass). This exposed the dung to the environmental conditions and allowed natural degradation to occur. For each individual ( $\mathrm{n}=66$ ), an initial odour sample was taken $<5$ minutes from defecation (Table 1). We then subsequently resampled each bolus four more times, at intervals 6, 12, 24, and 48 hours after defecation to create an odour degradation profile (total $n=264$ ). During this resampling period, the bolus remained as one solid bolus, except for territorial males who scatter their dung by kicking (Owen-Smith 1973). For these males, we left the dung scattered so that it could degrade in its natural state. We collected samples between March and December 2014, with the wet season defined as October-March and the dry season as April-September. This gave us a total of four months of wet season data (i.e. March, October-December) and six months dry season data (i.e. April-September). Differences in the sampling periods were determined by the ease with which we could locate white rhinos and collect sufficient dung samples. During the study, midday temperatures averaged $35^{\circ} \mathrm{C}$ and $75 \%$ humidity during the wet season, and $27^{\circ} \mathrm{C}$ and $56 \%$ during the dry season (Marneweck et al. unpublished data). The rainfall over these months was consistent with the ten-year average (wet season $=413$ $\mathrm{mm}$, dry season $=71 \mathrm{~mm})($ Ezemvelo KZN Wildlife, unpublished data).

Table 1 Number of individuals of each sex and state from which dung odour samples were collected each season.

\begin{tabular}{lccccc}
\hline & \multicolumn{2}{c}{ Male } & \multicolumn{2}{c}{ Female } \\
Season & Territorial & Non-territorial & Oestrous & Non-oestrous & Total \\
\hline Wet & 10 & 11 & 3 & 11 & 35 \\
Dry & 11 & 9 & 2 & 9 & 31 \\
Total & 21 & 20 & 5 & 20 & 66 \\
\hline
\end{tabular}


Odour samples were collected from a dung bolus using dynamic headspace extraction (Amirav and Dagan 1997). To do this we collected the air for 25 minutes from a dung bolus enclosed in a polyacetate bag using a micro-air sampler (Supelco PAS-500) with a realized flow rate of $150 \mathrm{ml} / \mathrm{min}$. VOCs emitted from the dung were captured in a small thermodesorption trap filled with $1 \mathrm{mg}$ of Tenax ${ }^{\circledR}$ and $1 \mathrm{mg}$ of Carbotrap ${ }^{\circledR}$. We limited sampling to 48 hours, as our pilot study data revealed that dung odours did not last longer than three days (supplementary material). With such short longevity, we assumed that vast changes would occur relatively quickly. Therefore, we chose shorter intervals for the beginning of the sampling period. We took control odour samples (ambient air) at random intervals, so that we could remove any VOCs present in similar concentrations within control samples (i.e. contaminants). However, we found no contaminants in the odours samples during this study.

Gas Chromatography-Mass Spectrometry Analysis of Dung Odours. We carried out gas chromatography-mass spectrometry (GC-MS) analysis of the odour samples on a Bruker 450 GC with a $30 \mathrm{~m} \times 0.25 \mathrm{~mm}$ internal diameter (film thickness $0.255 \mathrm{~mm}$ ) Varian VF-5ms column, connected to a Varian VF-1 ms column (11 m x $0.25 \mathrm{~mm}$ internal diameter, film thickness $0.25 \mathrm{~mm}$ ), coupled to a Bruker 300 quadrupole mass spectrometer in electronimpact ionization mode at $70 \mathrm{eV}$. Thermodesorption traps were placed in a Varian 1079 injector equipped with a chromatoprobe thermal desorption device. The flow of helium carrier gas was $1 \mathrm{ml} \mathrm{min}^{-1}$. We held the injector at an initial temperature of $250^{\circ} \mathrm{C}$ for 20 min. The split vent was programmed to start with a 10:1 split for 2 min and then to switch to splitless mode for 2 min to allow for thermal desorption, followed by a 100:1 split after 4.2 mins to clean the injector. After an initial temperature at $45^{\circ} \mathrm{C}$ the temperature of the GC oven was increased to $260^{\circ} \mathrm{C}$ at $7^{\circ} \mathrm{C} \mathrm{min}^{-1}$ and, after reaching $260^{\circ} \mathrm{C}$, held at this temperature for a total run time of $35 \mathrm{~min}$. We identified VOCs using Varian WORKSTATION software with the NIST 2011 mass spectral library (NIST/EPA/NIH Mass Spectral Library, data version: NIST 2011; Microsoft SEARCH software version $2.0 \mathrm{~d}$ ). We verified the identification of VOCs with retention times of authentic standards and published Kovats indices wherever possible (supplementary material).

Collection of Behavioural Data. To collect data on midden visitation and defecation, we setup motion-triggered video recording camera traps at ten middens, each with a different resident territorial male (identified via differences in horn shape and size), from October 2014 to August 2015. The males recorded here were different to the males from which dung odours were collected. We did this as we wanted to minimise contact with the individuals from which we were collecting behavioural data, as it may affect midden visitation patterns. We identified territorial males as adult males performing territorial specific behaviours (i.e. dung kicking, urine spraying), and non-territorial males as adult males not performing these behaviours. We recorded data on adults only and each adult was categorised as either territorial male, non-territorial male, or adult female. We grouped all adult females together for analysis, as it was not possible to identify oestrous state from the video footage. We used infrared 'no-glow' camera traps (either a Cuddeback Black Flash ${ }^{\circledR}$ E3 or Cuddeback Attack 
Black Flash 1194 model) placed approximately $3 \mathrm{~m}$ from the edge of the midden. We used 'no-glow' cameras as they do not emit visible light or have a flash, creating minimal disturbance at the midden and therefore allowing us to capture natural behaviour. We programmed the cameras to record 30 second videos at each trigger with a 1 second delay before becoming active again. From the 2403 videos, we created an ID profile for each adult to determine individual visitation and defecation.

Statistical Analysis. Absolute concentration of VOCs is subject to variability across samples, so we used relative abundance of a VOC within a sample (i.e. proportion) for statistical analysis. To determine if there was any short-term change in dung odour per season we carried out a PERMANOVA based on Bray-Curtis similarities of square-root transformed proportions for each male (territorial, non-territorial) and female state (oestrous, nonoestrous).

We define the odour signal persistence (or odour longevity) of dung as the duration for which odour differences in the VOC composition of different time groups were statistically detectable. This is based on the assumption that fresh dung should contain the highest information (in terms of predictability that another individual is in the same area). However, with increasing time after defecation, the differential loss of VOCs from the dung will reduce the information that the odour signal contains. At some time after defecation, the VOC composition of dung may reach such a high level of variation that it is difficult to distinguish them from samples of earlier defecation times. In other words, from an information theory perspective, environmental conditions, such as temperature and humidity, increase the noise to signal ratio of the odour signal, and that after a certain time most information is lost.

To test factors affecting individual VOC contribution, we ran a linear mixed-effects model using the $\mathrm{R}$ package nlme (Pinheiro et al. 2015). We set the proportion contribution of the VOC as the response variable, and season, time (i.e. hours from defecation), VOC functional group, plus their interactions, as fixed factors, and sample ID as a random factor. We repeated this for each male (territorial, non-territorial) and female state (oestrous, nonoestrous).

We interpreted the best predictors (i.e. VOCs) of dung age using the importance function of the randomForest package (Liaw and Wiener 2012) based on the metric mean decrease in accuracy (MDA). The MDA is the increase in the percentage of times the outcome is misclassified when the variable is randomised. A higher MDA means less misclassification, and thus greater accuracy, and ultimately indicates higher importance to the classification.

We calculated individual visitation and defecation frequency by the number of visits or defecations divided by the number of camera active days (range $=172-282$ active days). To assess seasonal differences in midden visitation and defecation frequency we ran a linear mixed-effects model. We set visitation or defecation frequency as the response variable, season as the fixed factor, and rhino ID as a random factor. We performed PERMANOVA tests in Primer version 6.1.15, and linear mixed-effects models and random forests in RStudio version 0.99.491. 


\section{RESULTS}

Short-term changes of dung odours

Territorial male dung odours underwent two significant changes during the wet season (Fig. 1a). Specifically, between 0-6 hours $(\mathrm{R}=1.968, \mathrm{P}=0.001)$ and $6-12$ hours $(\mathrm{R}=1.393, \mathrm{P}=$ 0.024). After 12 hours, no differences between the odour samples were detected (12-24 hours $\mathrm{R}=1.242, \mathrm{P}=0.163 ; 24-48$ hours $\mathrm{R}=1.375, \mathrm{P}=0.083$ ). Thus, the persistence of territorial male dung odours was approximately 12 hours during the wet season. During the dry season, significant differences were detected between 0-6 hour samples $(\mathrm{R}=1.936, \mathrm{P}=0.001), 6-12$ hours $(\mathrm{R}=1.617, \mathrm{P}=0.006)$, and $24-48$ hours $(\mathrm{R}=1.469, \mathrm{P}=0.031$; Fig. $1 \mathrm{~b})$. No differences were detected between the 12 and 24 hour samples $(\mathrm{R}=1.260, \mathrm{P}=0.146)$, indicating that the odours persisted for approximately 48 hours during the dry season, with noise increasing with dung age.

Non-territorial male dung odours differed significantly during the wet season between 12-24 hours ( $\mathrm{R}=1.494, \mathrm{P}=0.017$; Fig. $1 \mathrm{c}$ ). No differences were detected between $0-6$ hour samples $(\mathrm{R}=1.329, \mathrm{P}=0.062)$, 6-12 hour samples $(\mathrm{R}=0.880, \mathrm{P}=0.620)$, or $24-48$ hour samples $(\mathrm{R}=0.898, \mathrm{P}=0.597)$. Thus, non-territorial male dung odours persisted for approximately 24 hours during the wet season. No significant differences were detected between non-territorial male dung odour samples during the dry season $(0-6$ hours $\mathrm{R}=1.108$, $\mathrm{P}=0.280 ; 6-12$ hours $\mathrm{R}=0.870, \mathrm{P}=0.628 ; 12-24$ hours $\mathrm{R}=0.897, \mathrm{P}=0.559 ; 24-48$ hours $\mathrm{R}$ $=0.628, \mathrm{P}=0.927$; Fig. $1 \mathrm{~d}$ ), indicating that odours persist for over 48 hours. 

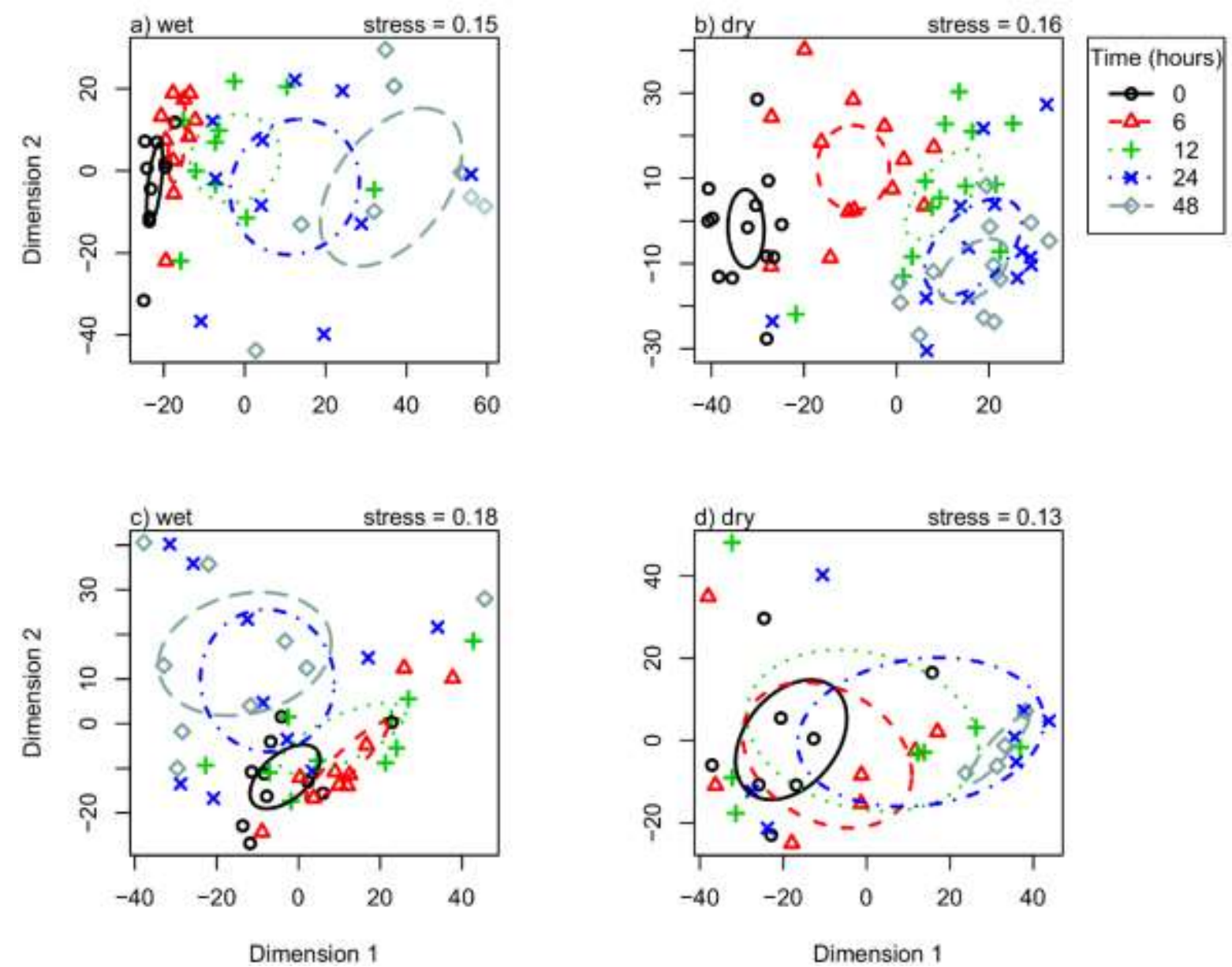

Fig. 1 Multidimensional scaling (MDS) plot based on Bray-Curtis similarities of the variation of VOCs emitted from territorial male dung over 48 hours during, (a) wet and (b) dry seasons, and from non-territorial male dung over 48 hours during, (c) wet and (d) dry seasons. Encompassing circles represent $95 \%$ confidence intervals.

We did not find differences between samples of oestrous female dung during the wet (0-6 hours $\mathrm{R}=1.213, \mathrm{P}=0.200 ; 6-12$ hours $\mathrm{R}=1.046, \mathrm{P}=0.413 ; 12-24$ hours $\mathrm{R}=1.184, \mathrm{P}=$ $0.412 ; 24-48$ hours $\mathrm{R}=1.439, \mathrm{P}=0.116$; Fig. $2 \mathrm{a})$, or dry season sampling periods $(0-6$ hours $\mathrm{R}=0.970, \mathrm{P}=0.660 ; 6-12$ hours $\mathrm{R}=0.724, \mathrm{P}=0.698 ; 12-24$ hours $\mathrm{R}=2.309, \mathrm{P}=0.320$; 24 48 hours $\mathrm{R}=1.230, \mathrm{P}=0.324$; Fig. $2 \mathrm{~b}$ ). This suggests that oestrous female dung odours persist for over 48 hours regardless of season. However, this may be an artefact of the low sample size ( $\mathrm{N}=5$ oestrous females).

In contrast to oestrous females, the dung odour of non-oestrous females differed significantly during the wet season $0-6$ hours $(\mathrm{R}=1.606, \mathrm{P}=0.019$; Fig. $2 \mathrm{c})$, but not during the any other time period (6-12 hours $\mathrm{R}=0.977, \mathrm{P}=0.442 ; 12-24$ hours $\mathrm{R}=1.432, \mathrm{P}=$ 0.056 ; $24-48$ hours $\mathrm{R}=0.843, \mathrm{P}=0.696$; Fig. $2 \mathrm{c})$. However, during the dry season, the odour of non-oestrous dung was similar to that of oestrous females in that it did not differ (0-6 hours $\mathrm{R}=1.285, \mathrm{P}=0.120 ; 6-12$ hours $\mathrm{R}=0.873, \mathrm{P}=0.678 ; 12-24$ hours $\mathrm{R}=1.137, \mathrm{P}=$ 0.213 ; 24-48 hours $\mathrm{R}=0.484, \mathrm{P}=0.965$; Fig. $2 \mathrm{~d}$ ). 

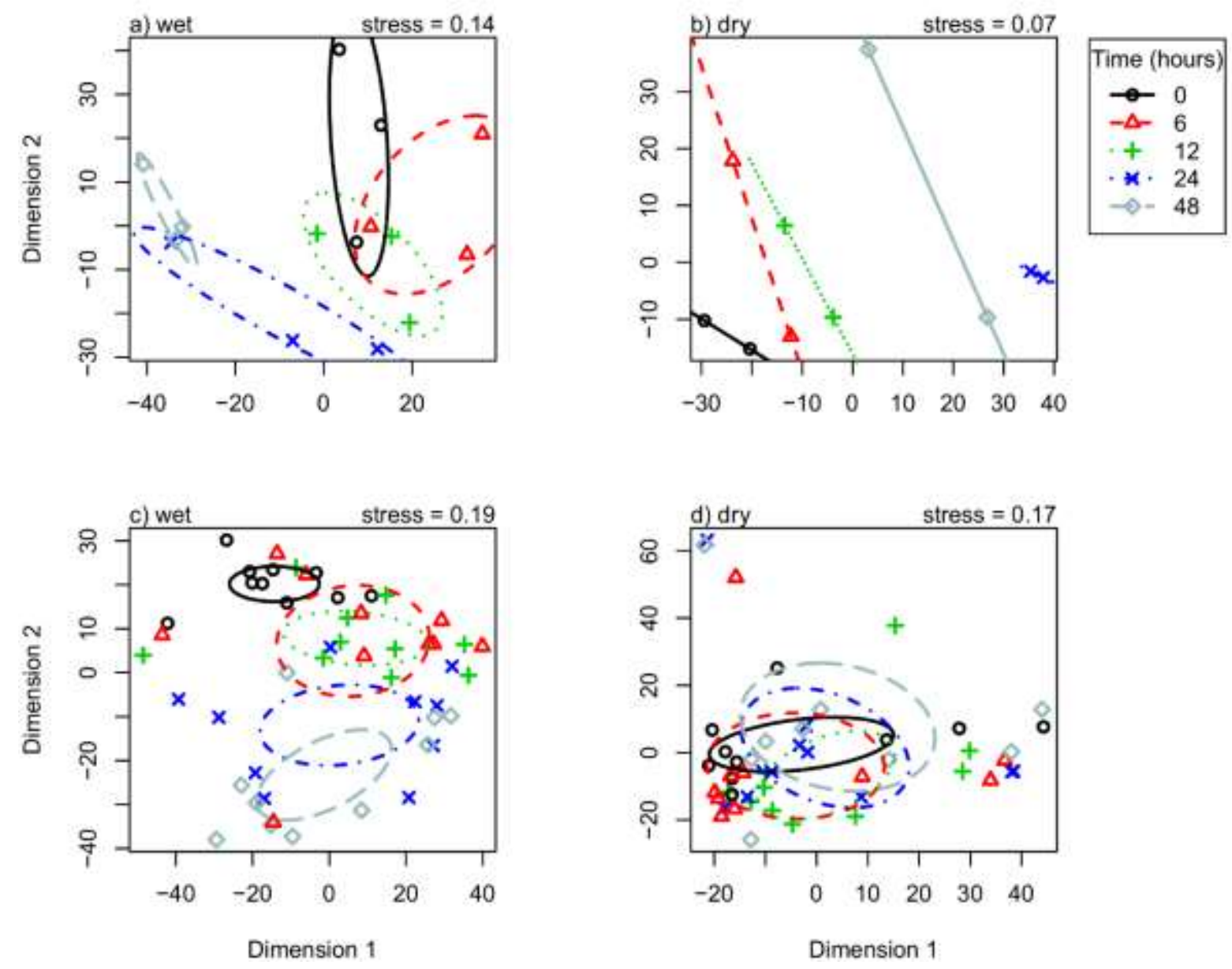

Fig. 2 Multidimensional scaling (MDS) plot based on Bray-Curtis similarities of the variation of VOCs emitted from oestrous female dung over 48 hours during, (a) wet and (b) dry seasons, and from non-oestrous female dung over 48 hours during, (c) wet and (d) dry seasons. Encompassing circles represent $95 \%$ confidence intervals.

\section{Long-term changes in dung odour composition}

The odour composition of territorial male dung was affected by a three-way interaction between season, time (i.e. hours from defecation) and VOC functional group $\left(F_{27}=2.857\right.$, $\mathrm{P}$ $<0.001)$. During the wet season, the proportion of monoterpenes, alkanes, alkenes, and ketones reduced over time. Sesquiterpenes and aldehydes increased over time, benzenoids remained consistent contributors to the odour, and acids showed a short-lived increase (Fig. 3a). Contrastingly, during the dry season the proportion of monoterpenes, alkanes, and alkenes reduced over time. Sesquiterpenes, benzenoids, and aldehydes increased over time, and both acids and ketones displayed a short-lived increase (Fig. 3b). In addition, the pattern of emission for benzenoids and ketones changed with season. The most important VOC for indicating the age of territorial male dung was the monoterpenoid 3,7-dimethyl-1,6-octadiene during the wet season (Fig. 5a), and the benzenoid acetophenone during the dry season (Fig. $5 b)$.

The odour composition of non-territorial male dung was effected by an interaction between season and VOC functional group $\left(F_{11}=10.596, \mathrm{P}<0.001\right)$, and between time (i.e. hours from defecation) and VOC functional group $\left(F_{44}=3.446, \mathrm{P}<0.001\right)$. Over time, the 
proportion of emitted monoterpenes decreased, and the proportion of sesquiterpenes, alkanes, alkenes, and aldehydes increased. Benzenoids remained a consistent contributor to the odours, while acids showed a short-lived increase (Fig. 3c,d). These changes (i.e. level of increase or decrease) were more apparent during the wet season. The most important VOC for indicating the age of non-territorial male dung was the monoterpenoid 3,7-dimethyl-1,6octadiene during the wet season (Fig. 5c), and the benzenoid toluene during the dry season (Fig. 5d).
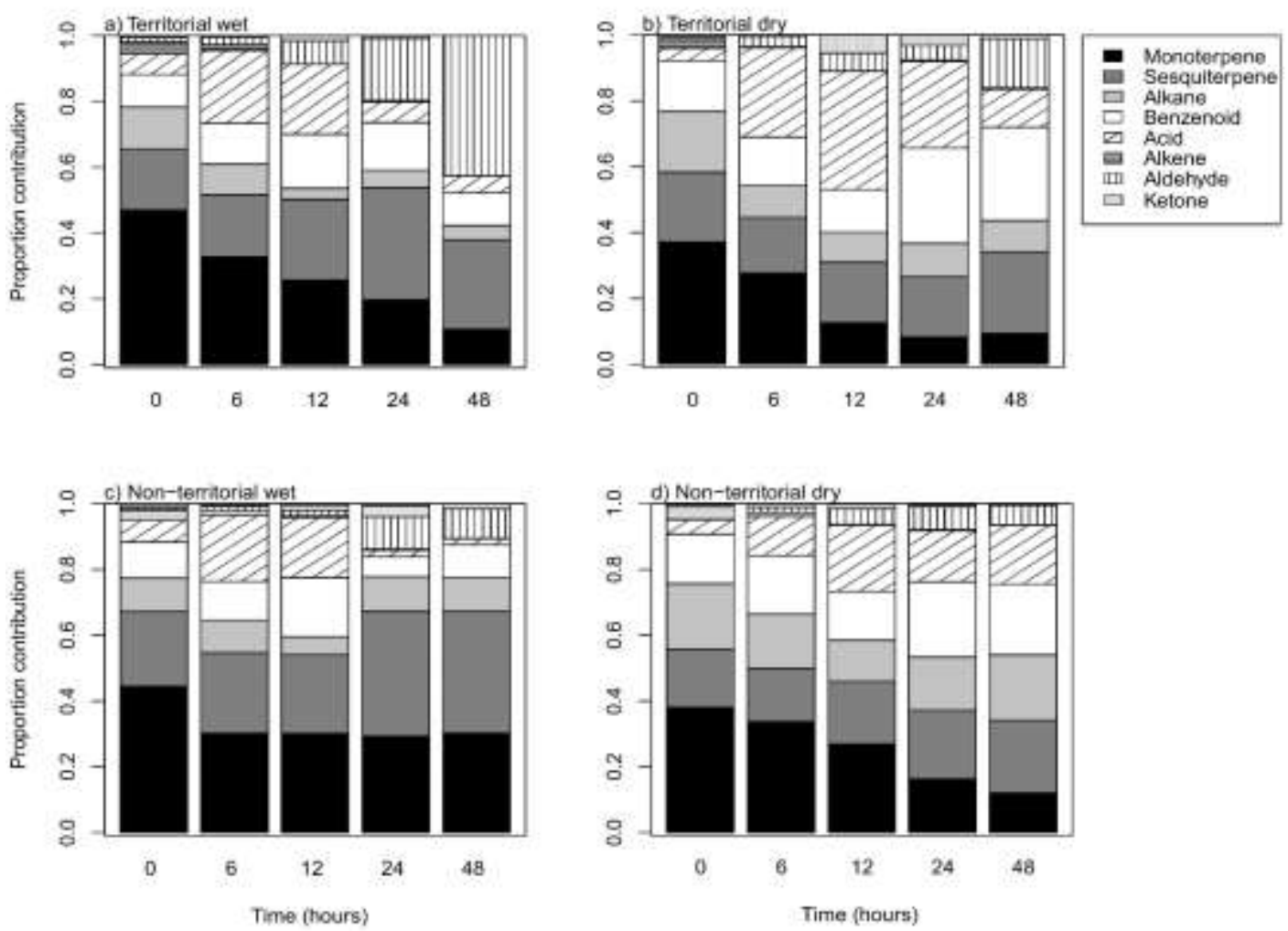

Fig. 3 Odour composition of territorial male dung over 48 hours during, the (a) wet and (b) dry seasons, and non-territorial male dung over 48 hours during, the (c) wet and (d) dry seasons.

The odour composition of oestrous female dung was affected by a three-way interaction between season, time (i.e. hours from defecation), and VOC functional group $\left(F_{44}\right.$ $=1.797, \mathrm{P}<0.001)$. During the wet season, the proportion of sesquiterpenes and aldehydes increased over time, whereas monoterpenes, alkanes, and alkenes decreased. Both benzenoids and acids had a short-lived increase, and ketones remained consistent contributors to the odour (Fig. 4a). In contrast, during the dry season the proportion of benzenoids, aldehydes, and ketones increased, whereas sesquiterpenes, alkanes, and alkenes decreased. Acids showed a short-lived increase, while monoterpenes were consistent contributors (Fig. 4b). The pattern of emission for sesquiterpenes, monoterpenes, benzenoids, and ketones changed with season. Regardless of season, the most important VOC for indicating the age of oestrous female dung was the benzenoid acetophenone (Fig. 5e,f).

Similar to oestrous female dung, the odour composition of non-oestrous female dung was also effected by a three-way interaction between season, time (i.e. hours from 
defecation), and VOC functional group $\left(F_{44}=1.981, \mathrm{P}<0.001\right)$. During the wet season, the proportion of sesquiterpenes, benzenoids, and aldehydes increased over time, whereas monoterpenes, alkanes, and alkenes decreased. Acids showed a short-lived increase, while ketones were consistent contributors (Fig. 4c). Contrastingly, during the dry season only the proportion of sesquiterpenes increased, while monoterpenes, alkanes, and alkenes all decreased. Both benzenoids and acids showed short-lived increases, and aldehydes and ketones were consistent contributors (Fig. 4d). The pattern of emission for benzenoids and aldehydes changed seasonally. The most important VOC for indicating the age of nonoestrous female dung was the monoterpenoid 3,7-dimethyl-1,6-octadiene during the wet season (Fig. 5g), and the benzenoid acetophenone during the dry season (Fig. 5h).
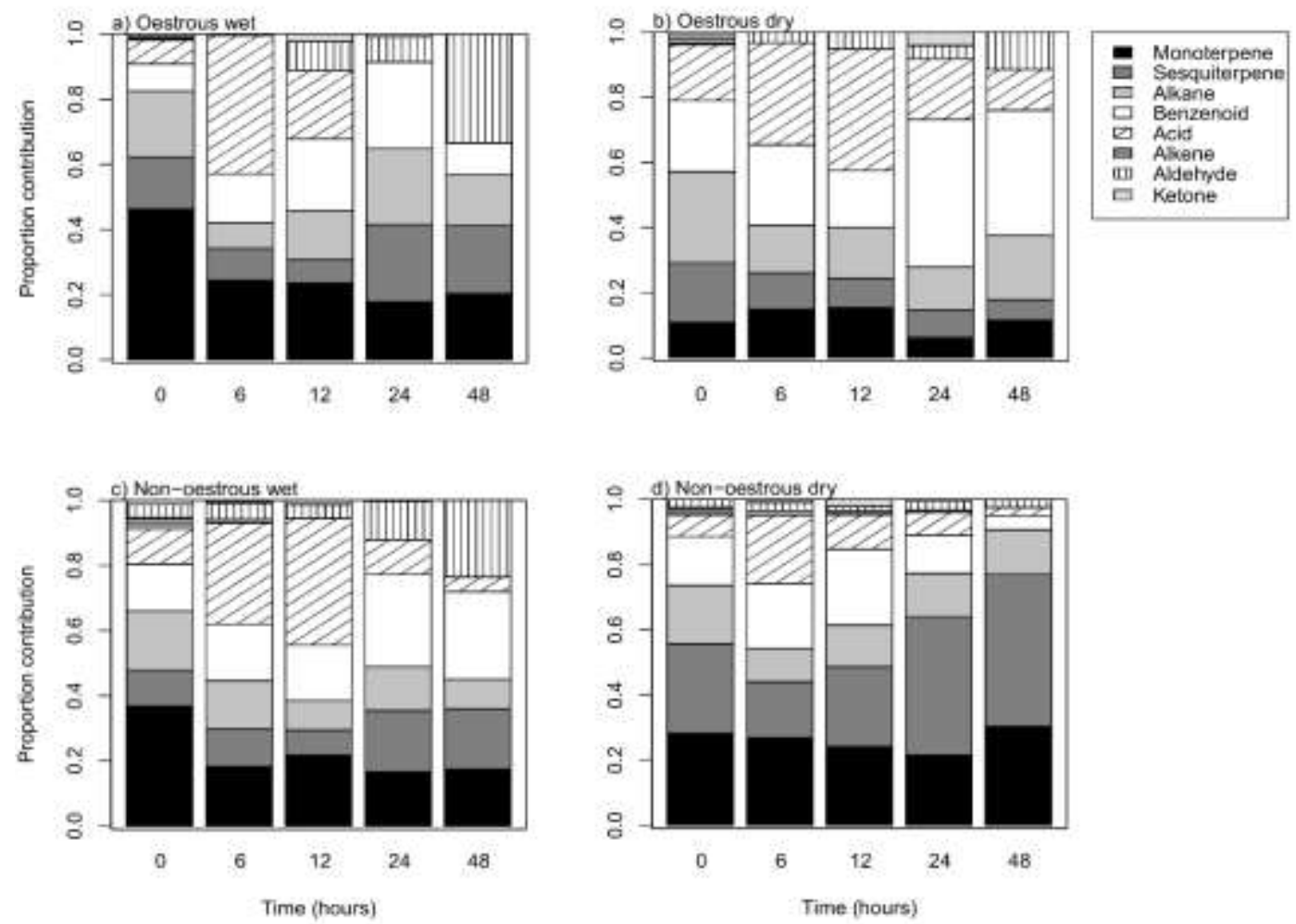

Fig. 4 Odour composition of oestrous female dung over 48 hours during, the (a) wet and (b) dry seasons, and non-oestrous female dung over 48 hours during, the (c) wet and (d) dry seasons. 


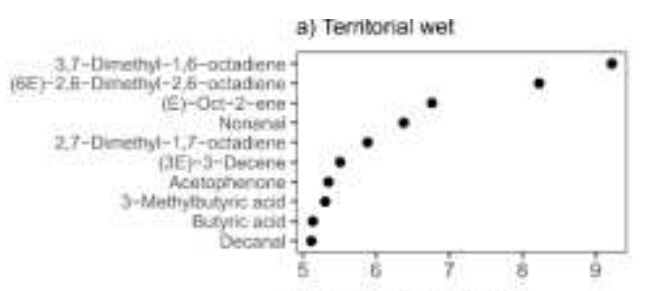

c) Non-territcrial wet
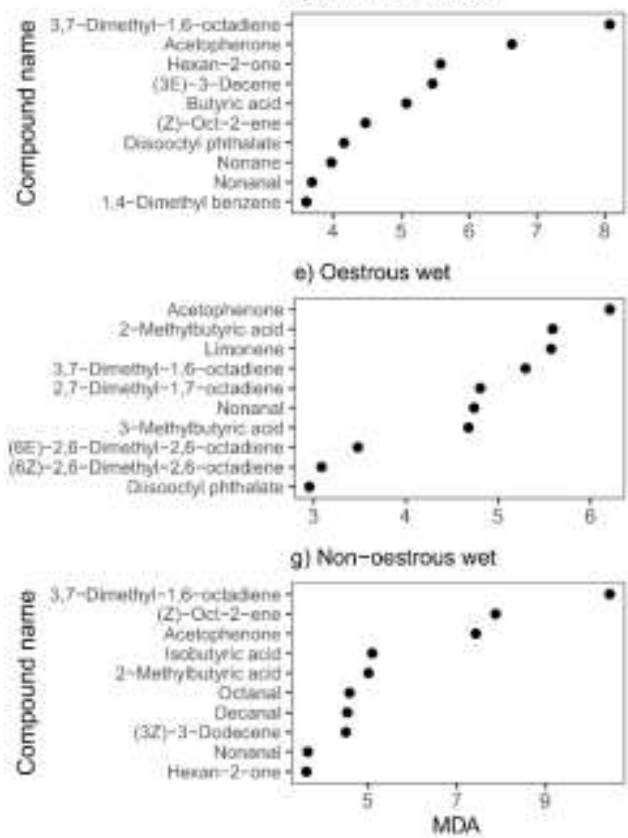

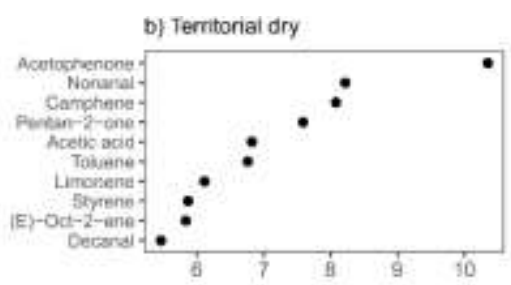

d) Non-territorial dry
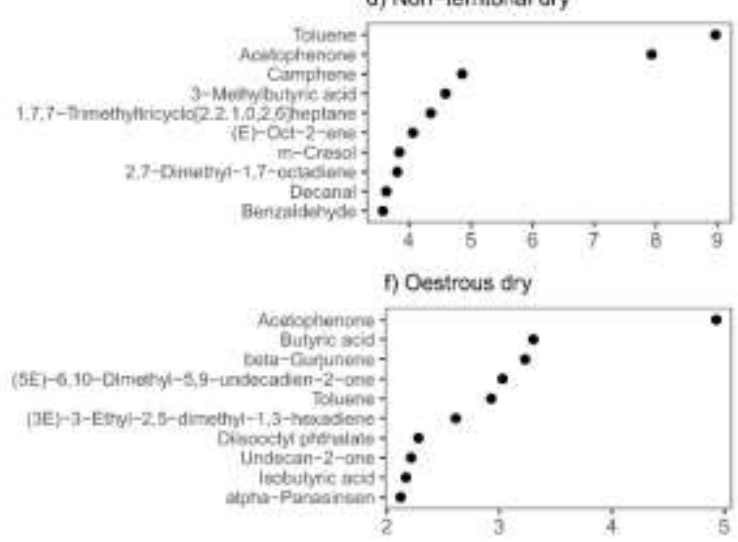

h) Non-oostrous dry

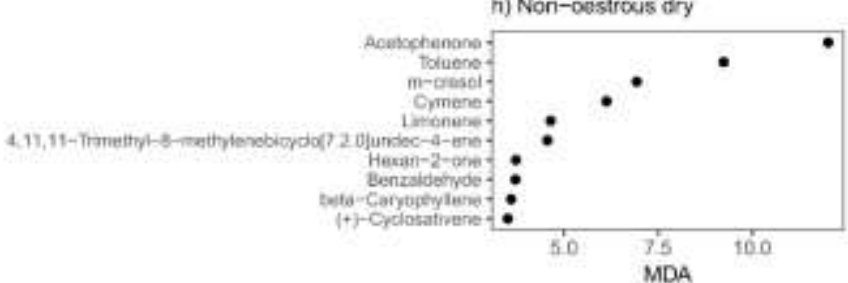

Fig. 5 The importance of volatile organic compounds (VOCs) for distinguishing the age of dung from territorial males, a) wet season, b) dry season; non-territorial males c) wet season, d) dry season; oestrous females e) wet season, f) dry season; and non-oestrous females g) wet season, h) dry season. Importance was based on mean decrease in accuracy (MDA). Only the top ten compounds are presented in the figure.

\section{Defecation frequency}

Season did not affect the midden visitation $(t=-1.024, \mathrm{P}=0.719$, Fig. 6a), or defecation frequency $(t=-0.363, \mathrm{P}=0.643$, Fig. $6 \mathrm{~b})$ of male or female adult white rhinos. 

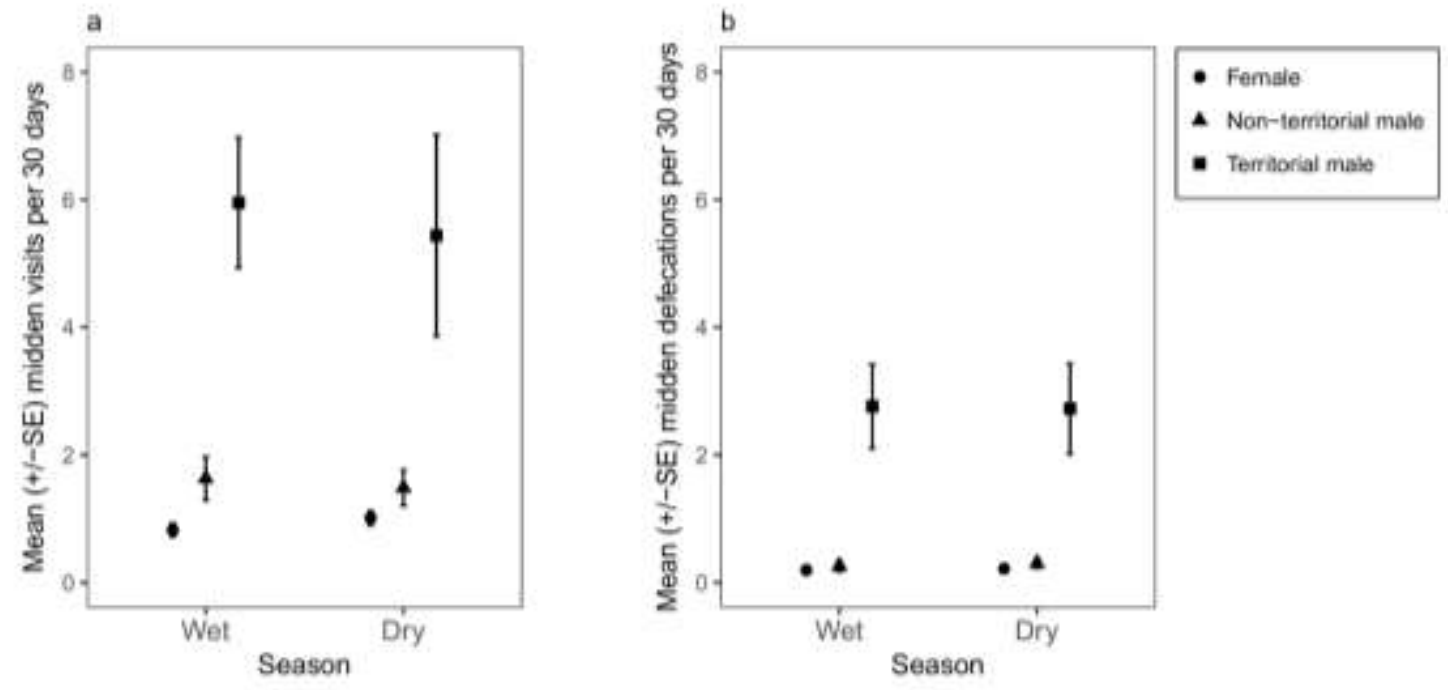

Fig. 6 Seasonal midden (a) visitation, and (b) defecation, of adult white rhinos.

\section{DISCUSSION}

The longevity of an olfactory signal has implications for an animal's fitness. In the case of marking with dung, it is very likely that information is lost over time because certain VOCs emitted from the dung will disappear. This is confirmed by our study. We found that older dung showed a much higher variation in their VOC composition than fresh dung. For territorial males, or oestrous females trying to attract mates, it makes evolutionary sense for signals to be long-lasting (Gosling and Roberts 2001a). In contrast, for individuals not breeding (e.g. non-territorial males, non-oestrous females), the duration of an olfactory signal is likely not as important. In line with these predictions, we found that the dung odours of oestrous white rhino females persisted for longer than non-oestrous females. However, dung odours of white rhino territorial males persisted for less time than non-territorial males. Seasonally, the dung odours of all adults persisted longer during the dry season, compared to the wet season. Yet, the decrease in wet season longevity did not elicit a change in white rhinos' defecation frequency or midden visitation. Additionally, we found three VOCs (of plant origin) that were important for distinguishing the age of white rhino dung. Ultimately, similar to glandular secretions (Buesching et al. 2002), our findings tend to suggest that dung can be a good source of information transfer, however, it is likely not as suitable for longterm transmission of olfactory information.

Scent marking with dung by white rhinos has a territorial role (Owen-Smith 1973). Middens occur throughout a male's territory, and territorial holders deposit dung in each midden approximately every 10 days (Owen-Smith 1971; Owen-Smith 1973). By defecating in middens found along the territory boundary, territorial males can signal territory ownership to rival males, and to any females entering the territory (Owen-Smith 1971; Owen-Smith 1973). Yet, to be effective, these signals need to persist for extended period of time, or be refreshed regularly prior to the signal dissipating (Gosling 1982; Gosling and Roberts 2001b). In our study, we found that territorial male dung odours were relatively short-lived compared 
to the dung odours of other adult white rhinos, persisting only 48 hours in the dry season, and then decreasing to approximately 12 hours during the wet season. The seasonal decrease in longevity of the territorial male odours, and the odours of the other adults, was likely due to environmental conditions. Average midday temperature and humidity at the study site were $35^{\circ} \mathrm{C}$ and $75 \%$ respectively in the wet season, compared to dry season $27^{\circ} \mathrm{C}$ and $56 \%$ (Marneweck et al. unpublished data). High temperatures and levels of humidity increase the emission of VOCs (Nimmermark and Gustafsson 2005; Peñuelas and Llusià 2001; Regnier and Goodwin 1977) and, as dung VOCs are finite, this likely caused a decrease in odour longevity. This likely affects territorial males more than other individuals because their dung emits more VOCs of high volatility (Marneweck et al. 2017; Marneweck et al. unpublished data), and thus are more susceptible to environmental changes.

Because of the decreased longevity of the dung odours during the wet season, we would have expected white rhinos, in particular territorial males, to increase their midden visitation and defecation frequency during this time to maintain their olfactory signals. This, however, was not the case. In contrast, neither territorial males nor any other adult white rhinos adjusted their midden visitation or defecation frequency. Non-territorial males and females do not experience seasonal changes in odour to the same degree that territorial males do, which may explain the lack of change in their seasonal defecation frequency. With regard to territorial males, we suggest that the lack of change is likely due to dung being a limited resource (Brachares and Arcese 1999), and that white rhinos are already defecating at the highest frequency possible for their physiology. Territorial white rhino males defecate smaller volumes than other adults, likely to increase their marking frequency (Marneweck et al. unpublished data). One way territorial males could potentially increase the number of middens they visit per day would be to reduce the amount of dung they defecate even further. This, however, would likely result in an even faster loss of information due to the increased surface area to volume ratio available for emission. A second possibility, is that during this critical time, territorial males may restrict their marking efforts to a few key middens within and along the borders of their territories. Determining this, however, was beyond the scope of our study.

With regard to reproduction, being able to determine the age of a dung mark is likely extremely important for territorial males. For example, as the average male territory is generally small ( $2 \mathrm{~km}^{2}$; Owen-Smith 1988), knowing approximately when an oestrous female defecated in a midden will allow the male to determine whether it is worth pursuing her. For oestrous females, long lasting oestrous odours would help ensure that males can find them while they are still in oestrus. White rhinos have monthly oestrus cycles (van der Goot et al. 2015) and breed year-round (Owen-Smith 1988). In line with this, we found that the dung odours of oestrous females were the only odours not to change seasonally. This would be advantageous for signalling to males irrespective of season. However, we must acknowledge that the apparent stability of the oestrous dung odours may be due to low sample size, and thus is worth exploring further.

The diet of an individual can influence the odours that it produces (Buesching et al. 2002; Macdonald et al. 2008). Yet, it has been suggested that odours that are influenced by genetics (e.g. sex) remain stable and detectable despite dietary changes (Kwak et al. 2008). 
We found that for white rhinos, the VOCs responsible for indicating the age of a dung mark (i.e. 3,7-dimethyl-1,6-octadiene, acetophenone, and toluene) originated from undigested vegetation present in the dung (Osbourn and Lanzotti 2009). However, we found that the VOCs that indicated dung age varied seasonally, where 3,7-dimethyl-1,6-octadiene indicated age during the wet season, and acetophenone during the dry season. This shift could be related to white rhinos shifting their diet in the dry season as a way of coping with decreasing food quality (Shrader et al. 2006). Further, as these VOC indicators of dung age are unimportant for signalling white rhino characteristics such as sex (Marneweck et al. 2017), they provide a separate set of information for individuals to assess dung age. Thus, white rhinos are most likely able to detect the sex and status of an individual (e.g. territorial male, oestrous female), as well as approximately when the dung was deposited.

Up until our study, an understanding of the detailed temporal changes of dung VOCs has been lacking. Our results show that vast changes in the dung odours of white rhinos occur relatively quickly. In a previous study (Marneweck et al. 2017), we found that white rhinos were able to recognise sex, age, territorial and oestrous state from the odour of fresh dung. The findings of our present study expand on this by indicating that it is likely that white rhinos are also able to determine the age of the dung from odour changes, and thus respond accordingly. In contrast to the dung odours of white rhinos, Buesching et al. (2002) found that individual-specific information in the glandular secretions of European badgers was relatively stable, with only two VOCs negatively correlated with time. Additionally, klipspringers responded to glandular marks seven days after deposition (Roberts 1998), and male golden hamsters (Mesocricetus auratus) responded to female glandular marks that were 40 days old (Johnston and Schmidt 1979). Although individual-specific information in white rhino dung is not as stable as glandular secretions, there is information available on the age of the dung, while the signal is still active. However, the short longevity and instability of white rhino dung odours highlights some of the key limitations of marking with dung.

\section{REFERENCES}

Amirav A, Dagan S. 1997. A direct sample introduction device for mass spectrometry studies and gas chromatorgraphy mass spectrometry anlyses. European Journal of Mass Spectrometry 3:105-111.

Archunan G, Rajagopal T. 2013. Detection of estrus in Indian blackbuck: Behavioural, hormonal and urinary volatiles evaluation. General and Comparitive Endocrinology 181:156-166.

Beauchamp GK, Berüter J. 1973. Source and stability of attractive components in guinea pig (Cavia porcellus) urine. Behavioral Biology 9:43-47.

Brachares JS, Arcese P. 1999. Scent marking in a territorial African antelope: II. The economics of marking with faeces. Animal Behaviour 57:11-17.

Buesching CD, Tinnesand HV, Sin Y, Rosell F, Burke T, Macdonald DW. 2016. Coding of Group Odor in the Subcaudal Gland Secretion of the European Badger Meles meles: Chemical Composition and Pouch Microbiota. In: Schulte BA, Goodwin TE, Ferkin 
MH, editors. Chemical Signals in Vertebrates 13. Cham: Springer International Publishing. p 45-62.

Buesching CD, Waterhouse JS, Macdonald DW. 2002. Gas-chromatographic analyses of the subcaudal gland secretion of the European badger (Meles meles) part II: time-related variation in the individual-specific composition. Journal of Chemical Ecology 28:5769.

Darden SK, Steffensen LK, Dabelsteen T. 2008. Information transfer among widely spaced individuals: latrines as a basis for communication networks in the swift fox? Animal Behaviour 75:425-432.

Gosling LM. 1982. A reassessment of the function of scent marking in territories. Z. Tierpsychol. 60:89-118.

Gosling LM, Roberts SC. 2001a. Scent-marking by male mammals: cheat-proof signals to competitors and mates. Advances in the Study of Behavior 30:169-217.

Gosling LM, Roberts SC. 2001b. Testing ideas about the function of scent marks in territories from spatial patterns. Animal Behaviour 62:F7-F10.

Hillman-Smith AKK, Owen-Smith N, Anderson JL, Hall-Martin AJ, Selaladi JP. 1986. Age estimation of the white rhinoceros (Ceratotherium simum). Journal of Zoology 210:355-379.

Hurst JL, Robertson DHL, Tolladay U, Beynon RJ. 1998. Proteins in urine scent marks of male house mice extend the longevity of olfactory signals. Animal Behaviour 55:1289-1297.

Johnston RE, Schmidt T. 1979. Responses of hamsters to scent marks of different ages. Behavioral and Neural Biology 26:64-75.

Kretzschmar P. 2002. Ecological, endocrinological and ethological investigations of female mate choice in free-ranging white rhinoceros (Ceratotherium simum simum): ErnstMoritz-Arndt-Universität Greifswald.

Kwak J, Willse A, Matsumura K, Opiekun M, Yi W, Preti G, Yamazaki K, Beauchamp G. 2008. Genetically-based olfactory signatures persist despite dietary variation. PLoS ONE 3:10.

Leclaire S, Nielsen JF, Drea CM. 2014. Bacterial communities in meerkat anal scent secretions vary with host sex, age, and group membership. Behavioral Ecology 24:996-1004.

Liaw A, Wiener M. 2012. Classification and regression by randomForest. R News 2:18-22.

Lindemann H. 1982. African rhinoceroses in captivity: University of Copenhagen.

Lunt N, Mhlanga MR. 2011. Defecation rate variability in the common duiker: importance of food quality, season, sex and age. South African Journal of Wildlife Research 41:2935.

Lydell K, Doty RL. 1972. Male rat odor preferences for female urine as a function of sexual experience, urine age, and urine source. Hormones and Behavior 3:205-212.

Macdonald E, Fernandez-Duque E, Evans S, Hagey L. 2008. Sex, age, and family differences in the chemical composition of owl monkey (Aotus nancymaae) subcaudal scent secretions. American Journal of Primatology 70:12-18. 
Marneweck C, Jürgens A, Shrader AM. 2017. Dung odours signal sex, age, territorial and oestrous state in white rhinos. Proceedings of the Royal Society B: Biological Sciences 284:20162376.

Marneweck D, Cameron EZ, Ganswind A, Dalerum F. 2015. Behavioural and endocrine correlates to the aardwolf mating system. Mammalian Biology 80:31-38.

Martín J, López P. 2013. Effects of global warming on sensory ecology of rock lizards: increased temperatures alter the efficacy of sexual chemical signals. Functional Ecology 27:1332-1340.

Nimmermark S, Gustafsson G. 2005. Influence of temperature, humidity and ventilation rate on the release of odor and ammonia in a floor housing system for laying hens. Agricultural Engineering International 7:1-14.

Oliveira DGR, Macedo RH. 2010. Functional context of scent-marking in Callithrix penicillata. Folia Primatologica 81:73-85.

Osbourn AE, Lanzotti V. 2009. Plant-derived Natural Products: Synthesis, Function, and Application: Springer New York.

Owen-Smith N. 1971. Territoriality in the white rhinoceros (Ceratotherium simum) Burchell. Nature 231:294-296.

Owen-Smith N. 1973. The behavioural ecology of the white rhinoceros. Madison, USA: University of Wisconsin.

Owen-Smith N. 1988. Megaherbivores. The influence of very large body size on ecology. Cambridge, UK: Cambridge University Press.

Peñuelas J, Llusià J. 2001. The complexity of factors driving volatile organic compound emissions by plants. Biologia Plantarum 44:481-487.

Pinheiro J, Bates D, DebRoy S, Sarkar D, Team RC. 2015. nlme: linear and nonlinear mixed effects model. R package version 3.1-120.

Ralls K, Smith DA. 2004. Latrine use by San Joaquin kit foxes (Vulpes macrotis mutica) and coyotes (Canis latrans). West North American Naturalist 64:544-547.

Regnier FE, Goodwin M. 1977. On the chemical and environmental modulation of pheromone release from vertebrate scent marks. In: Müller-Schwarze D, Mozell MM, editors. Chemical Signals in Vertebrates: Springer US. p 115-133.

Roberts SC. 1998. Behavioural responses to scent marks of increasing age in klipspringer Oreotragus oreotragus. Ethology 104:585-592.

Roper TJ, Conradt L, Butler J, Christian SE, Ostler J, Schmid TK. 1993. Territorial marking with faeces in badgers (Meles meles): a comparison of boundary and hinterland latrine use. Behaviour 127:289-307.

Shrader AM, Owen-Smith N, Ogutu JO. 2006. How a mega-grazer copes with the dry season: food and nutrient intake rates by white rhinoceros in the wild. Functional Ecology 20:376-384.

Stoddart DM. 1976. Mammalian odours and pheromones. London, UK: Edward Arnold Ltd.

Stoffel MA, Caspers BA, Forcada J, Giannakara A, Baier M, Eberhart-Phillips L, Muller C, Hoffman JI. 2015. Chemical fingerprints encode mother-offspring similarity, colony membership, relatedness, and genetic quality in fur seals. Proceedings of the National Academy of Sciences U.S.A. 112:E5005-12. 
van der Goot AC, Martin GB, Millar RP, Paris MC, Ganswindt A. 2015. Profiling patterns of fecal 20-oxopregnane concentrations during ovarian cycles in free-ranging southern white rhinoceros (Ceratotherium simum simum). Animal Reproduction Science 161:89-95.

Verheggen FJ, Haubruge E, Mescher MC. 2010. Alarm pheromones: chemical signaling in response to danger. Vitamins \& Hormones 83:215-239.

White AM, Swaisgood R, Czekala N. 2007. Ranging patterns in white rhinoceros, Ceratotherium simum simum: implications for mating strategies. Animal Behaviour 74:349-356.

Wilson JK, Kessler A, Woods HA. 2015. Noisy Communication via Airborne Infochemicals. BioScience 65:667-677.

Zala SM, Potts WK, Penn DJ. 2004. Scent-marking displays provide honest signals of health and infection. Behavioral Ecology 15:338-344. 


\section{Appendix 1: All identified volatile organic compounds from white rhino dung}

Table A1. Volatile organic compounds distinguished from all samples of white rhino dung odour. Compound identification criteria and notes: $\mathrm{a}=$ comparison of MS with published data; $\mathrm{b}=$ comparison of MS and retention time with published data; $\mathrm{c}=$ comparison of MS and retention time with authentic standard.

\begin{tabular}{|c|c|c|c|c|}
\hline Compound name & Functional group & $\begin{array}{l}\text { Retention } \\
\text { time }\end{array}$ & CAS \# & $\begin{array}{l}\text { KOVA } \\
\text { TS } \\
\text { index }\end{array}$ \\
\hline Acetic acid ${ }^{\mathrm{c}}$ & Hydrocarbon acid & 1.681 & $64-19-7$ & 645 \\
\hline Propanoic acid ${ }^{b}$ & Hydrocarbon acid & 2.514 & $79-09-4$ & 710 \\
\hline Isobutyric acid $^{\mathrm{b}}$ & Hydrocarbon acid & 3.396 & $79-31-2$ & 765 \\
\hline Butyric acid ${ }^{b}$ & Hydrocarbon acid & 4.019 & $107-92-6$ & 789 \\
\hline 3-Methylbutyric acid & Hydrocarbon acid & 4.976 & $503-74-2$ & 848 \\
\hline 2-Methylbutyric acid ${ }^{b}$ & Hydrocarbon acid & 5.397 & $116-53-0$ & 863 \\
\hline Pentanoic acid $^{\mathrm{b}}$ & Hydrocarbon acid & 5.800 & $109-52-4$ & 841 \\
\hline Butylacetic acid $^{b}$ & Hydrocarbon acid & 8.038 & $1070-83-3$ & 952 \\
\hline Butylethylacetic acid $^{b}$ & Hydrocarbon acid & 11.129 & $149-57-5$ & 1123 \\
\hline Nonanoic acid ${ }^{\mathrm{b}}$ & Hydrocarbon acid & 14.126 & $112-05-0$ & 1273 \\
\hline Undecanoic acid & Hydrocarbon acid & 19.561 & $112-37-8$ & 1561 \\
\hline Hexadecanoic acid $^{\mathrm{b}}$ & Hydrocarbon acid & 25.602 & $112-39-0$ & 1870 \\
\hline Octadecanoic acid $^{\mathrm{b}}$ & Hydrocarbon acid & 28.380 & $57-11-4$ & 2171 \\
\hline Octanoic acid $^{\mathrm{a}}$ & Hydrocarbon acid & 29.666 & $124-07-2$ & - \\
\hline Butan-1-ol $^{\mathrm{b}}$ & Hydrocarbon alcohol & 2.272 & $71-36-3$ & 653 \\
\hline 3-Methyl-2-butanol ${ }^{\mathrm{a}}$ & Hydrocarbon alcohol & 2.764 & $598-75-4$ & - \\
\hline 3-Methyl-1-butanol ${ }^{\mathrm{b}}$ & Hydrocarbon alcohol & 3.159 & $123-51-3$ & 737 \\
\hline Pentan-1-ol ${ }^{b}$ & Hydrocarbon alcohol & 3.665 & $71-41-0$ & 766 \\
\hline$(3 \mathrm{E})-3-$ Hexen-1-ol ${ }^{\mathrm{b}}$ & Hydrocarbon alcohol & 5.238 & $544-12-7$ & 845 \\
\hline Hexan-1-ol $^{b}$ & Hydrocarbon alcohol & 5.637 & $111-27-3$ & 860 \\
\hline 6-Methyl-3-heptanol ${ }^{b}$ & Hydrocarbon alcohol & 8.352 & $589-98-0$ & 991 \\
\hline (2E)-2-Nonen-1-ol ${ }^{\mathrm{a}}$ & Hydrocarbon alcohol & 9.695 & $31502-14-4$ & - \\
\hline 3-Nonanol ${ }^{\mathrm{a}}$ & Hydrocarbon alcohol & 9.909 & $624-51-1$ & - \\
\hline Nonan-2-ol ${ }^{b}$ & Hydrocarbon alcohol & 10.939 & $628-99-9$ & 1100 \\
\hline Undecan-1-ol $^{\mathrm{a}}$ & Hydrocarbon alcohol & 11.005 & $112-42-5$ & - \\
\hline Nonan-1-ol ${ }^{b}$ & Hydrocarbon alcohol & 12.432 & $112-42-5$ & 1169 \\
\hline 2-Methyl-1-undecanol ${ }^{\mathrm{a}}$ & Hydrocarbon alcohol & 15.881 & $10522-26-6$ & - \\
\hline 2-Butyl-1-octanol ${ }^{\mathrm{a}}$ & Hydrocarbon alcohol & 16.220 & $3913-02-8$ & - \\
\hline (9E)-9-Hexadecen-1-ol ${ }^{\mathrm{a}}$ & Hydrocarbon alcohol & 27.377 & $64437-47-4$ & - \\
\hline Pentanal $^{\mathrm{b}}$ & Hydrocarbon aldehyde & 2.645 & $110-62-3$ & 693 \\
\hline Hexanal $^{\mathrm{c}}$ & Hydrocarbon aldehyde & 4.234 & $66-25-1$ & 776 \\
\hline (2E)-2-Hexanal ${ }^{b}$ & Hydrocarbon aldehyde & 5.253 & $6728-26-3$ & 850 \\
\hline Heptanal $^{\mathrm{c}}$ & Hydrocarbon aldehyde & 6.256 & $111-71-7$ & 901 \\
\hline (2Z)-2-Heptenal ${ }^{b}$ & Hydrocarbon aldehyde & 7.445 & $57266-86-1$ & 952 \\
\hline Octanal $^{\mathrm{c}}$ & Hydrocarbon aldehyde & 8.449 & $124-13-0$ & 1003 \\
\hline (2E)-2-Nonanal ${ }^{\mathrm{a}}$ & Hydrocarbon aldehyde & 9.912 & $18829-56-6$ & - \\
\hline Nonanal $^{\mathrm{c}}$ & Hydrocarbon aldehyde & 10.976 & $124-19-6$ & 1103 \\
\hline
\end{tabular}




\begin{tabular}{|c|c|c|c|c|}
\hline Decanal $^{\text {c }}$ & Hydrocarbon aldehyde & 13.166 & $112-31-2$ & 1205 \\
\hline Tetradecanal $^{\text {b }}$ & Hydrocarbon aldehyde & 20.409 & $124-25-4$ & 1574 \\
\hline$(9 \mathrm{Z})-9-$ Octadecenal $^{\mathrm{b}}$ & Hydrocarbon aldehyde & 27.830 & $2423-10-1$ & - \\
\hline (9Z)-9-Hexadecenal ${ }^{b}$ & Hydrocarbon aldehyde & 30.430 & $56219-04-6$ & - \\
\hline 2-Methylpentane ${ }^{\mathrm{b}}$ & Hydrocarbon alkane & 1.882 & $107-83-5$ & 560 \\
\hline 3-Methylpentane ${ }^{b}$ & Hydrocarbon alkane & 1.962 & $96-14-0$ & 570 \\
\hline Hexane $^{c}$ & Hydrocarbon alkane & 1.927 & $110-54-3$ & 600 \\
\hline Methylcyclopentane $^{b}$ & Hydrocarbon alkane & 2.265 & $96-37-7$ & 635 \\
\hline 3-Ethylhexane ${ }^{c}$ & Hydrocarbon alkane & 4.180 & $619-99-8$ & 772.9 \\
\hline 2,4-Dimethylheptane ${ }^{b}$ & Hydrocarbon alkane & 4.649 & $2213-23-2$ & 820 \\
\hline 4-Methyloctane ${ }^{b}$ & Hydrocarbon alkane & 5.475 & $2216-34-4$ & 862.85 \\
\hline Nonane $^{c}$ & Hydrocarbon alkane & 6.411 & $111-84-2$ & 900 \\
\hline Decane $^{c}$ & Hydrocarbon alkane & 8.658 & $124-18-5$ & 1000 \\
\hline 4-Methyldecane ${ }^{b}$ & Hydrocarbon alkane & 9.004 & $2847-72-5$ & 1059 \\
\hline 6-Methyloctadecane ${ }^{a}$ & Hydrocarbon alkane & 11.506 & $10544-96-4$ & - \\
\hline 3-Methyldecane ${ }^{a}$ & Hydrocarbon alkane & 12.340 & $13151-34-3$ & - \\
\hline 2-Methylundecane ${ }^{b}$ & Hydrocarbon alkane & 12.194 & $7045-71-8$ & 1163 \\
\hline 2,3-Dimethyldecane ${ }^{\mathrm{a}}$ & Hydrocarbon alkane & 12.497 & $17312-44-6$ & - \\
\hline Undecane $^{c}$ & Hydrocarbon alkane & 13.099 & $629-59-4$ & 1100 \\
\hline Dodecane $^{c}$ & Hydrocarbon alkane & 13.222 & $112-40-3$ & 1200 \\
\hline 2,6-Dimethylundecane ${ }^{b}$ & Hydrocarbon alkane & 13.376 & $17301-23-4$ & 1213 \\
\hline Pentadecane $^{\mathrm{a}}$ & Hydrocarbon alkane & 14.120 & $629-62-9$ & - \\
\hline 2,3-Dimethylundecane ${ }^{a}$ & Hydrocarbon alkane & 14.432 & $17312-77-5$ & - \\
\hline 2-Methyldecane ${ }^{a}$ & Hydrocarbon alkane & 14.347 & $6975-98-0$ & - \\
\hline Nonadecane $^{\mathrm{a}}$ & Hydrocarbon alkane & 14.517 & $629-92-5$ & - \\
\hline Tridecane $^{c}$ & Hydrocarbon alkane & 15.217 & $629-50-5$ & 1300 \\
\hline 2,6,10-Trimethyldodecane ${ }^{\mathrm{a}}$ & Hydrocarbon alkane & 18.233 & $3891-98-3$ & - \\
\hline Pentadecane $^{c}$ & Hydrocarbon alkane & 18.935 & $629-62-9$ & - \\
\hline Hexadecane $^{c}$ & Hydrocarbon alkane & 20.636 & $544-76-3$ & - \\
\hline Heptadecane $^{\mathrm{c}}$ & Hydrocarbon alkane & 22.288 & $629-78-7$ & - \\
\hline Octadecane $^{c}$ & Hydrocarbon alkane & 23.858 & $593-45-3$ & - \\
\hline Isopropyl Myristate $^{\mathrm{b}}$ & Hydrocarbon alkane & 23.649 & $110-27-0$ & 1827 \\
\hline Isopropyl Palmitate $^{\mathrm{b}}$ & Hydrocarbon alkane & 27.008 & $142-91-6$ & 1981 \\
\hline Tetracosane $^{b}$ & Hydrocarbon alkane & 31.307 & $646-31-1$ & 2400 \\
\hline Pentacosane $^{\mathrm{b}}$ & Hydrocarbon alkane & 32.684 & $630-02-4$ & 2500 \\
\hline Hexacosane $^{b}$ & Hydrocarbon alkane & 34.319 & $630-01-3$ & 2600 \\
\hline (E)-Oct-2-ene ${ }^{b}$ & Hydrocarbon alkene & 4.319 & $111-67-1$ & 810 \\
\hline (Z)-Oct-2-ene ${ }^{b}$ & Hydrocarbon alkene & 4.379 & $7642-04-8$ & 815 \\
\hline X-Octene & Hydrocarbon alkene & 4.485 & - & - \\
\hline X-Octene & Hydrocarbon alkene & 4.601 & - & - \\
\hline (3E)-1,3-Octadiene ${ }^{b}$ & Hydrocarbon alkene & 4.784 & $1002-33-1$ & 827 \\
\hline Non-1-ene ${ }^{a}$ & Hydrocarbon alkene & 6.215 & $124-11-8$ & - \\
\hline$(3 \mathrm{E})-3-$ Nonene $^{\mathrm{a}}$ & Hydrocarbon alkene & 6.228 & $20063-77-8$ & - \\
\hline $\begin{array}{l}\text { (4E)-2,4-Dimethyl-2,4- } \\
\text { heptadiene }^{\text {a }}\end{array}$ & Hydrocarbon alkene & 5.850 & 74421-05-9 & - \\
\hline (3E)-3-Decene ${ }^{\mathrm{a}}$ & Hydrocarbon alkene & 7.773 & $19150-21-1$ & - \\
\hline
\end{tabular}




\begin{tabular}{|c|c|c|c|c|}
\hline Undec-1-ene $^{\mathrm{a}}$ & Hydrocarbon alkene & 10.734 & $821-95-4$ & - \\
\hline (3Z)-3-Dodecene ${ }^{a}$ & Hydrocarbon alkene & 13.055 & $7239-23-8$ & - \\
\hline Tridecene- $1^{\mathrm{b}}$ & Hydrocarbon alkene & 15.060 & $2437-56-1$ & 1291 \\
\hline Acetic acid, butyl ester ${ }^{b}$ & Hydrocarbon ester & 4.515 & $123-86-4$ & 813 \\
\hline $\begin{array}{l}\text { Octadecanoic acid, phenylmethyl } \\
\text { ester }^{c}\end{array}$ & Hydrocarbon ester & 10.932 & $637-55-8$ & - \\
\hline Butyl n-hexanoate $^{b}$ & Hydrocarbon ester & 12.825 & $626-82-4$ & 1186 \\
\hline Dodecanyl acetate $^{\mathrm{b}}$ & Hydrocarbon ester & 20.290 & $122-66-3$ & 1606 \\
\hline Pentan-2-one ${ }^{b}$ & Hydrocarbon ketone & 2.432 & $107-87-9$ & 690 \\
\hline Hexan-2-one $^{b}$ & Hydrocarbon ketone & 4.029 & $591-78-6$ & $7-90$ \\
\hline 5-Methylhexan-2-one ${ }^{\mathrm{a}}$ & Hydrocarbon ketone & 5.991 & $110-12-3$ & \\
\hline 1-Octen-3-one ${ }^{b}$ & Hydrocarbon ketone & 8.112 & $4312-99-6$ & 980 \\
\hline beta-Nonanone $^{\mathrm{b}}$ & Hydrocarbon ketone & 10.644 & $821-55-6$ & 1090 \\
\hline Undecan-2-one $^{\mathrm{b}}$ & Hydrocarbon ketone & 14.953 & $112-12-9$ & 1292 \\
\hline Dodecan-2-one $^{\mathrm{a}}$ & Hydrocarbon ketone & 14.608 & $6175-49-1$ & - \\
\hline Toluene $^{\mathrm{c}}$ & Benzenoid & 3.726 & $108-88-3$ & 762 \\
\hline alpha-Methyltoluene $^{\mathrm{b}}$ & Benzenoid & 5.561 & $100-41-4$ & 855 \\
\hline 1,4-Dimethyl benzene ${ }^{c}$ & Benzenoid & 5.696 & $106-42-3$ & 862 \\
\hline Styrene $^{\mathrm{c}}$ & Benzenoid & 6.224 & $100-42-5$ & 895 \\
\hline $\begin{array}{l}\text { 4-Ethylbenzoic acid, cyclopentyl } \\
\text { ester }^{\mathrm{a}}\end{array}$ & Benzenoid & 6.522 & & - \\
\hline 1-Ethyl-3-methylbenzene ${ }^{b}$ & Benzenoid & 7.622 & $98-82-8$ & 958 \\
\hline Benzaldehyde $^{c}$ & Benzenoid & 7.769 & $100-52-7$ & 947 \\
\hline $\begin{array}{l}\text { Carbamic acid, methyl-, phenyl } \\
\text { ester }^{\mathrm{a}}\end{array}$ & Benzenoid & 7.975 & $1943-79-9$ & - \\
\hline Trimethyl benzene $^{b}$ & Benzenoid & 8.110 & $95-63-6$ & 990 \\
\hline Acetophenone $^{\mathrm{c}}$ & Benzenoid & 10.137 & $98-86-2$ & 1062 \\
\hline p-Cresol ${ }^{\mathrm{c}}$ & Benzenoid & 10.717 & $106-44-5$ & 1077 \\
\hline m-Cresol ${ }^{c}$ & Benzenoid & 10.525 & $108-39-4$ & - \\
\hline 1-Isopropenyl-2-methylbenzene ${ }^{\mathrm{a}}$ & Benzenoid & 10.492 & $7399-49-7$ & - \\
\hline Phenylethyl Alcohol $^{\mathrm{c}}$ & Benzenoid & 11.180 & $60-12-8$ & 1121 \\
\hline Benzenepropanol $^{\mathrm{b}}$ & Benzenoid & 13.401 & $122-97-4$ & 1237 \\
\hline $\begin{array}{l}\text { 1-Isopropyl-2-methoxy-4- } \\
\text { methylbenzene }^{a}\end{array}$ & Benzenoid & 13.721 & $1076-56-8$ & - \\
\hline 3-Propylphenol ${ }^{\mathrm{a}}$ & Benzenoid & 14.195 & $621-27-2$ & - \\
\hline $\begin{array}{l}\text { Benzaldehyde, 3-hydroxy-4- } \\
\text { methoxy }^{\text {a }}\end{array}$ & Benzenoid & 16.978 & $621-59-0$ & - \\
\hline Diethyltoluamide $^{\mathrm{a}}$ & Benzenoid & 20.208 & $134-62-3$ & - \\
\hline $\begin{array}{l}\text { 5-Isopropenyl-2- } \\
\text { methylcyclohexanol }^{\text {a }}\end{array}$ & Miscellaneous & 7.457 & $18675-33-7$ & - \\
\hline $\begin{array}{l}\text { (3E)-2,6-Dimethyl-1,3,7- } \\
\text { octatriene }^{\mathrm{a}}\end{array}$ & Miscellaneous & 7.898 & $6876-07-9$ & - \\
\hline 1-Propynylcyclohexane ${ }^{a}$ & Miscellaneous & 7.930 & $18736-95-3$ & - \\
\hline (2E)-3,7-Dimethyl-2-octene ${ }^{\mathrm{a}}$ & Miscellaneous & 7.951 & - & - \\
\hline 5,7-Dimethyl-1,6-octadiene ${ }^{\mathrm{a}}$ & Miscellaneous & 8.152 & $85006-04-8$ & - \\
\hline 1-Methyl-3-\{2-methyl-2- & Miscellaneous & 8.113 & $75873-00-6$ & - \\
\hline
\end{tabular}




\begin{tabular}{|c|c|c|c|c|}
\hline propenyl)cyclopentane $^{\mathrm{a}}$ & & & & \\
\hline 6-Methyl-5-heptene-2-one ${ }^{b}$ & Miscellaneous & 8.232 & $110-93-0$ & 984 \\
\hline $\begin{array}{l}\text { (6E)-2,6-Dimethyl-2,6- } \\
\text { octadiene }^{\text {b }}\end{array}$ & Miscellaneous & 8.332 & $2609-23-6$ & 1004 \\
\hline 1,2-Dimethyl-1-cyclooctene ${ }^{a}$ & Miscellaneous & 8.335 & $54299-96-6$ & - \\
\hline $\begin{array}{l}\text { 1-Isopropyl-2-methyl-3-(1- } \\
\text { methylethylidene)cyclopropane }\end{array}$ & Miscellaneous & 8.451 & $24524-52-5$ & - \\
\hline $\begin{array}{l}\text { (6Z)-2,6-Dimethyl-2,6- } \\
\text { octadiene }^{\text {a }}\end{array}$ & Miscellaneous & 8.636 & $2492-22-0$ & - \\
\hline $\begin{array}{l}\text { (3E)-3-Ethyl-2-methyl-1,3- } \\
\text { heptadiene }^{\text {a }}\end{array}$ & Miscellaneous & 8.562 & $61142-35-6$ & - \\
\hline Pentylidenecyclopentane $^{\mathrm{a}}$ & Miscellaneous & 8.869 & $53366-55-5$ & - \\
\hline $\begin{array}{l}\text { (3E)-3-Ethyl-2,5-dimethyl-1,3- } \\
\text { hexadiene }^{\text {a }}\end{array}$ & Miscellaneous & 8.922 & $62338-07-2$ & - \\
\hline 2-Ethylhexan-1-ol ${ }^{\mathrm{a}}$ & Miscellaneous & 9.060 & $104-76-7$ & - \\
\hline m-Menth-3(8)-ene ${ }^{a}$ & Miscellaneous & 9.218 & $13828-34-7$ & - \\
\hline m-Menth-1(7)-ene ${ }^{a}$ & Miscellaneous & 9.223 & $13837-71-3$ & - \\
\hline $\begin{array}{l}\text { (3- } \\
\text { Methylbutylidene)cyclopentane }{ }^{\mathrm{a}}\end{array}$ & Miscellaneous & 9.253 & $53366-51-1$ & - \\
\hline (5E)-4-Methyl-1,5-heptadiene ${ }^{\mathrm{a}}$ & Miscellaneous & 9.813 & $998-94-7$ & - \\
\hline $\begin{array}{l}\text { (6E)-2,6-Dimethyl-2,6- } \\
\text { octadiene }^{\text {b }}\end{array}$ & Miscellaneous & 9.780 & $2792-39-4$ & 990 \\
\hline 3-Ethyl-1,5-octadiene ${ }^{\mathrm{a}}$ & Miscellaneous & 9.872 & - & - \\
\hline $\begin{array}{l}\text { 1-Isopropenyl-2- } \\
\text { methylcyclohexane }^{a}\end{array}$ & Miscellaneous & 10.003 & $15193-25-6$ & - \\
\hline (2E,6E)-4-Methyl-2,6-octadiene ${ }^{\mathrm{a}}$ & Miscellaneous & 10.078 & $74498-94-5$ & - \\
\hline 4,8-Dimethyl-1,7-nonadiene ${ }^{\mathrm{a}}$ & Miscellaneous & 10.099 & $62108-28-5$ & - \\
\hline $\begin{array}{l}2,5- \\
\text { Dimethyloctahydropentalene }^{a}\end{array}$ & Miscellaneous & 9.973 & $28588-55-8$ & - \\
\hline $\begin{array}{l}\text { 6,6-Dimethylbicyclo[3.1.1]hept- } \\
\text { 2-ene-2-carbaldehyde }{ }^{\text {b }}\end{array}$ & Miscellaneous & 11.088 & $564-94-3$ & 1151 \\
\hline 2-Ethylcyclohexanone ${ }^{\mathrm{a}}$ & Miscellaneous & 11.410 & $4423-94-3$ & - \\
\hline $\begin{array}{l}\text { 1,2-Dimethyl-1,3- } \\
\text { cyclopentadiene }^{\mathrm{a}}\end{array}$ & Miscellaneous & 11.691 & $4784-86-5$ & - \\
\hline 4-Trifluoroacetoxytridecane ${ }^{a}$ & Miscellaneous & 12.404 & - & - \\
\hline p-Menthan-3-one ${ }^{a}$ & Miscellaneous & 12.415 & $1196-31-2$ & - \\
\hline $\begin{array}{l}\text { 1-Methyl-4-(1-hydroxy-1- } \\
\text { methylethyl) benzene }\end{array}$ & Miscellaneous & 12.828 & $1197-01-9$ & 1186 \\
\hline alpha-lonene $^{\mathrm{a}}$ & Miscellaneous & 13.468 & $475-03-6$ & - \\
\hline Hexyl 2-methylbutanoate $^{b}$ & Miscellaneous & 13.792 & $10032-15-2$ & 1234 \\
\hline Guanidineacetic acid $^{\mathrm{a}}$ & Miscellaneous & 13.845 & $352-97-6$ & - \\
\hline 6,7-Dodecanedione ${ }^{\mathrm{a}}$ & Miscellaneous & 13.845 & $13757-90-9$ & - \\
\hline Quinoline $^{\mathrm{a}}$ & Miscellaneous & 13.984 & $91-22-5$ & - \\
\hline p-Mentha-6,8-dien-2-one ${ }^{\mathrm{a}}$ & Miscellaneous & 14.050 & $2244-16-8$ & - \\
\hline p-Menth-1-en-3-one ${ }^{a}$ & Miscellaneous & 14.278 & $89-81-6$ & - \\
\hline (3E)-4-(2-Hydroxy-2,6,6- & Miscellaneous & 15.679 & $55955-46-9$ & - \\
\hline
\end{tabular}




\begin{tabular}{|c|c|c|c|c|}
\hline $\begin{array}{l}\text { trimethylcyclohexyl)-3-buten-2- } \\
\text { one }^{\text {a }}\end{array}$ & & & & \\
\hline Bicyclo[10.1.0]tridec-1-ene ${ }^{\mathrm{a}}$ & Miscellaneous & 17.092 & $54766-91-5$ & - \\
\hline $\begin{array}{l}\text { (5E)-2,3,5,8-Tetramethyl-1,5,9- } \\
\text { decatriene }^{\text {a }}\end{array}$ & Miscellaneous & 17.128 & $230646-72-7$ & - \\
\hline $\begin{array}{l}\text { 1,5,9-Undecatriene, } \\
\text { trimethyl- }^{\mathrm{a}}\end{array}$ & Miscellaneous & 17.161 & 62951-96-6 & - \\
\hline $\begin{array}{l}\text { 6,11-Dimethyl-2,6,10- } \\
\text { dodecatrien-1-ol }^{\mathrm{a}}\end{array}$ & Miscellaneous & 17.642 & - & - \\
\hline $\begin{array}{l}\text { (5E)-6,10-Dimethyl-5,9- } \\
\text { undecadien-2-one }{ }^{\mathrm{a}}\end{array}$ & Miscellaneous & 17.959 & $3796-70-1$ & 1445 \\
\hline 2-Hexyl-1-decanol ${ }^{\mathrm{a}}$ & Miscellaneous & 18.126 & $2425-77-6$ & - \\
\hline $\begin{array}{l}\text { (4E,8E)-5,9,13-Trimethyl- } \\
4,8,12 \text {-tetradecatrienal }{ }^{\mathrm{a}}\end{array}$ & Miscellaneous & 19.137 & $66408-55-7$ & - \\
\hline $\begin{array}{l}\text { (6E)-3,7,11-Trimethyl-1,6,10- } \\
\text { dodecatrien-3-ol }^{\text {a }}\end{array}$ & Miscellaneous & 19.597 & $7212-44-4$ & 1561 \\
\hline 2,3,6-Trimethylnaphthalene ${ }^{\mathrm{a}}$ & Miscellaneous & 19.943 & $829-26-5$ & 1548 \\
\hline $\begin{array}{l}\text { 1-[2-(Isobutyryloxy)-1- } \\
\text { methylethyl]-2,2-dimethylpropyl } \\
\text { 2-methylpropanoate }{ }^{{ }^{a}}\end{array}$ & Miscellaneous & 20.472 & 74381-40-1 & - \\
\hline 3,7,11-Trimethyl-1-dodecanol ${ }^{\mathrm{a}}$ & Miscellaneous & 23.169 & $6750-34-1$ & - \\
\hline $\begin{array}{l}\text { 6,10,14-Trimethyl-2- } \\
\text { pentadecanone }^{\mathrm{a}}\end{array}$ & Miscellaneous & 24.441 & $502-69-2$ & 1848 \\
\hline $\begin{array}{l}\text { (2E)-3,7,11,15-Tetramethyl-2- } \\
\text { hexadecene }^{\text {b }}\end{array}$ & Miscellaneous & 24.487 & $14237-73-1$ & - \\
\hline $\begin{array}{l}\text { 1,2-Benzenedicarboxylic acid, } \\
\text { dibutyl ester }\end{array}$ & Miscellaneous & 25.569 & $84-74-2$ & 1897 \\
\hline 1-(Octyloxy)octane ${ }^{\mathrm{a}}$ & Miscellaneous & 26.179 & $629-82-3$ & - \\
\hline $\begin{array}{l}\text { (2E)-3,7,11,15-Tetramethyl-2- } \\
\text { hexadecen-1-ol }^{\text {b }}\end{array}$ & Miscellaneous & 27.708 & $150-86-7$ & 2112 \\
\hline $\begin{array}{l}\text { 2-Ethylhexyl (2E)-3-(4- } \\
\text { methoxyphenyl)-2-propenoate }^{\mathrm{a}}\end{array}$ & Miscellaneous & 28.855 & $5466-77-3$ & - \\
\hline $\begin{array}{l}\text { (9Z)-9-Octadecenyl } \\
\text { hexadecenoate }^{\text {a }}\end{array}$ & Miscellaneous & 32.353 & $22393-98-2$ & - \\
\hline $\begin{array}{l}1,7,7- \\
\text { Trimethyltricyclo[2.2.1.0,2,6]hep } \\
\text { tane }^{\mathrm{a}}\end{array}$ & Monoterpene & 6.983 & $508-32-7$ & 924 \\
\hline 2,7-Dimethyl-1,7-octadiene ${ }^{\mathrm{a}}$ & Monoterpene & 7.069 & $59840-10-7$ & - \\
\hline alpha-Pinene $^{c}$ & Monoterpene & 7.264 & $80-56-8$ & 932 \\
\hline 3,7-Dimethyl-1,6-octadiene ${ }^{\mathrm{a}}$ & Monoterpene & 7.395 & $10281-55-7$ & - \\
\hline 3,7-Dimethyl-1,6-octadiene ${ }^{a}$ & Monoterpene & 7.541 & $2436-90-0$ & - \\
\hline Camphene $^{b}$ & Monoterpene & 7.615 & $79-92-5$ & 946 \\
\hline beta-Pinene $^{c}$ & Monoterpene & 8.275 & $127-91-3$ & 980 \\
\hline alpha-Terpinolene $^{\mathrm{a}}$ & Monoterpene & 8.722 & $586-62-9$ & - \\
\hline 2-Carene ${ }^{\mathrm{a}}$ & Monoterpene & 8.764 & $554-61-0$ & - \\
\hline alpha-Phellandrene $^{b}$ & Monoterpene & 8.898 & $99-83-2$ & 1007 \\
\hline
\end{tabular}




\begin{tabular}{|c|c|c|c|c|}
\hline alpha-Terpine $^{c}$ & Monoterpene & 9.110 & $99-86-5$ & - \\
\hline Cymene $^{\mathrm{a}}$ & Monoterpene & 9.257 & $527-84-4$ & - \\
\hline Limonene $^{c}$ & Monoterpene & 9.405 & $1461-27-4$ & 1039 \\
\hline $\begin{array}{l}\text { 3,7,7- } \\
\text { Trimethylbicyclo[4.1.0]hept-3- } \\
\text { ene }^{\mathrm{a}}\end{array}$ & Monoterpene & 9.939 & $13466-78-9$ & - \\
\hline gamma-Terpinen $^{\mathrm{a}}$ & Monoterpene & 10.031 & $99-85-4$ & - \\
\hline Geranial $^{\mathrm{a}}$ & Monoterpene & 10.371 & $141-27-5$ & - \\
\hline Linalool $^{\mathrm{c}}$ & Monoterpene & 10.637 & $78-70-6$ & 1096 \\
\hline p-Mentha-1,4(8)-diene ${ }^{\mathrm{a}}$ & Monoterpene & 10.668 & $586-62-9$ & - \\
\hline $\begin{array}{l}\text { 1,7,7-Trimethylbicyclo } \\
{\left[2.2 .1 \text { heptan-2-ol }^{\mathrm{b}}\right.}\end{array}$ & Monoterpene & 12.591 & $507-70-0$ & 1174 \\
\hline Indole $^{c}$ & Nitrogen compound & 14.670 & $120-72-9$ & 1295 \\
\hline Benzyl nitrile $^{\mathrm{a}}$ & Nitrogen compound & 14.822 & $140-29-4$ & - \\
\hline 3-Methyl-1H-indole ${ }^{c}$ & Nitrogen compound & 16.846 & $83-34-1$ & - \\
\hline Allo-Aromadendrene $^{a}$ & Sesquiterpene & 16.312 & $25246-27-9$ & - \\
\hline alpha-Longipinene $^{\mathrm{b}}$ & Sesquiterpene & 16.418 & 5989-08-2 & 1353 \\
\hline 2,3-Dimethyldodecane ${ }^{a}$ & Sesquiterpene & 16.441 & $6117-98-2$ & - \\
\hline Farnesane $^{\mathrm{a}}$ & Sesquiterpene & 16.666 & $3891-98-3$ & - \\
\hline$(+)-C y c l o s a t i v e n e^{a}$ & Sesquiterpene & 16.733 & $22469-52-9$ & - \\
\hline gamma-Muurolene $^{a}$ & Sesquiterpene & 16.813 & $30021-74-0$ & - \\
\hline alpha-Copaene $^{\mathrm{a}}$ & Sesquiterpene & 16.817 & $3856-25-5$ & 1392 \\
\hline alpha-Bourbonene $^{\mathrm{a}}$ & Sesquiterpene & 16.997 & - & - \\
\hline beta-Elemene $^{\mathrm{a}}$ & Sesquiterpene & 17.074 & $515-13-9$ & - \\
\hline $\begin{array}{l}\text { 4,11,11-Trimethyl-8- } \\
\text { methylenebicyclo[7.2.0]undec-4- } \\
\text { ene }^{\mathrm{a}}\end{array}$ & Sesquiterpene & 17.431 & $118-65-0$ & 1413 \\
\hline alpha-Santalene $^{\mathrm{a}}$ & Sesquiterpene & 17.220 & $512-61-8$ & 1420 \\
\hline beta-Caryophyllene $^{\mathrm{c}}$ & Sesquiterpene & 17.715 & $87-44-5$ & 1440 \\
\hline Germacrene $\mathrm{D}^{\mathrm{a}}$ & Sesquiterpene & 17.841 & $23986-74-5$ & 1464 \\
\hline $\begin{array}{l}\text { 2,6-Dimethyl-6-(4-methyl-3- } \\
\text { pentenyl)bicyclo[3.1.1]hept-2- } \\
\text { ene }^{\mathrm{a}}\end{array}$ & Sesquiterpene & 17.459 & $17699-05-7$ & 1436 \\
\hline beta-Gurjunene $^{a}$ & Sesquiterpene & 17.914 & $17334-55-3$ & 1427.7 \\
\hline alpha-Caryophyllene $^{a}$ & Sesquiterpene & 18.357 & $6753-98-6$ & 1459 \\
\hline Aromadendrene $^{\mathrm{a}}$ & Sesquiterpene & 18.458 & 109119-91-7 & 1460 \\
\hline alpha-Muurolene $^{\mathrm{b}}$ & Sesquiterpene & 18.619 & $10208-80-7$ & - \\
\hline alpha-Amorphene $^{\mathrm{a}}$ & Sesquiterpene & 18.650 & $483-75-0$ & 1468 \\
\hline beta-Farnesene $^{a}$ & Sesquiterpene & 18.788 & $18794-84-8$ & 1458 \\
\hline $\begin{array}{l}\text { 1-Methyl-4-(5-methyl-1- } \\
\text { methylene-4-hexenyl)-1- } \\
\text { cyclohexene }^{\mathrm{a}}\end{array}$ & Sesquiterpene & 18.748 & $495-61-4$ & 1501.2 \\
\hline Calamenene $^{\mathrm{a}}$ & Sesquiterpene & 19.059 & $483-77-2$ & 1516 \\
\hline delta-Cadinene $^{a}$ & Sesquiterpene & 19.400 & $483-76-1$ & - \\
\hline alpha-Panasinsen $^{\mathrm{a}}$ & Sesquiterpene & 19.495 & $56633-28-4$ & - \\
\hline alpha-Calacorene $^{\mathrm{a}}$ & Sesquiterpene & 19.814 & $21391-99-1$ & - \\
\hline
\end{tabular}




\begin{tabular}{|l|l|l|l|l|}
\hline (Methyldisulfanyl)methane $^{\mathrm{a}}$ & Sulphur compound & 3.322 & $624-92-0$ & 745 \\
\hline Isopropyl isothiocyanate $^{\mathrm{a}}$ & Sulphur compound & - & $2253-73-8$ & - \\
\hline 3-(Allylsulfanyl)-1-propene & $\mathrm{a}$ \\
\hline $\begin{array}{l}\text { 1-Isothiocyanato-2- } \\
\text { methylpropane }^{\mathrm{a}}\end{array}$ & Sulphur compound & 5.441 & $592-88-1$ & 860.3 \\
\hline Thiacyclopentan-2-one $^{\mathrm{a}}$ & Sulphur compound & 7.353 & $591-82-2$ & - \\
\hline 3-(Allyldisulfanyl)-1-propene & & & \\
\hline
\end{tabular}




\section{Appendix 2: Pilot study investigating longevity of dung odours}

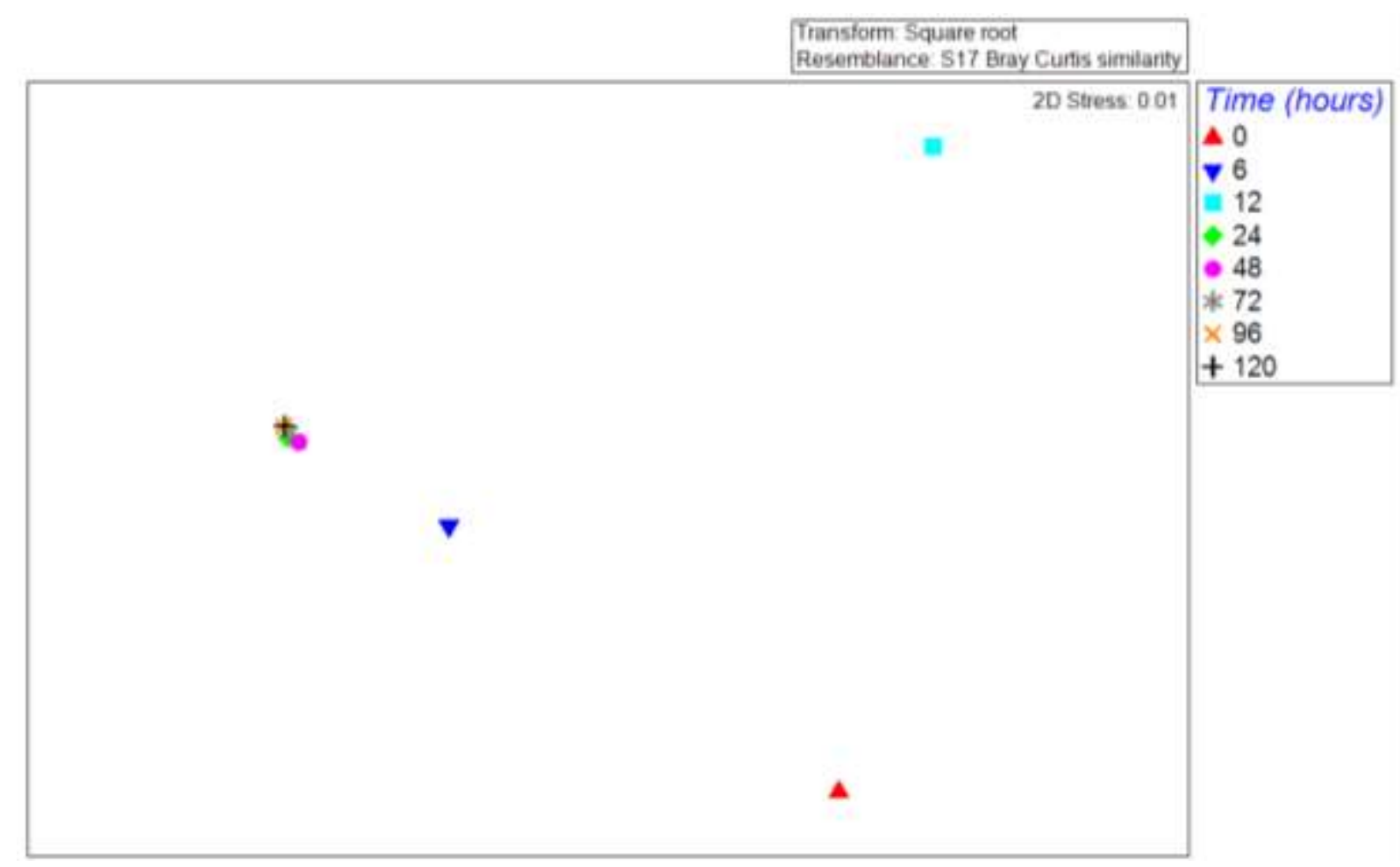

Figure A1. Multidimensional scaling (MDS) plot based on Bray-Curtis similarities of the variation of VOCs emitted from white rhino dung over 120 hours. After 48 hours the samples are clumped together meaning that the odours have lost any diverse information they were carrying, i.e. no longer effective as olfactory signals. 